\title{
The Differential Expression of 16 NMDA and Non-NMDA Receptor Subunits in the Rat Spinal Cord and in Periaqueductal Gray
}

\author{
T. R. Tölle, ${ }^{1}$ A. Berthele, ${ }^{1}$ W. Zieglgänsberger, ${ }^{1}$ P. H. Seeburg, ${ }^{2}$ and W. Wisden ${ }^{2, a}$ \\ ${ }^{1}$ Max-Planck-Institut für Psychiatrie, Klinisches Institut, Klinische Neuropharmakologie, 8000 Munich 40, Germany, and \\ 2ZMBH, Universität Heidelberg, Heidelberg, Germany
}

\begin{abstract}
Diverse arrays of glutamate-gated channels in the spinal cord and associated pathways are partly responsible for sensory input, for altered sensitivity to peripheral stimuli during inflammation, and for generation of motor patterns. The expression of 16 genes, encoding all known subunits for the NMDA receptor (NR1, NR2A to NR2D), AMPA/lowaffinity kainate (GluR-A to -D), high-affinity kainate ionotropic receptors (KA-1, -2, GiuR-5 to -7) and two orphan receptor subunits ( $\delta-1$ and -2 ) was examined by in situ hybridization in rat lumbar spinal cord, and in the periaqueductal gray. Subunit mRNAs for GluR-A, -B Flip, KA-2, and NR1 were abundant in the dorsal horn, with NR2D lightly expressed. Occasional cells in lamina II contained NR2C mRNA. While the GluR-A gene was preferentially expressed in laminae I and II-outer, GluR-B mRNA was evenly expressed throughout all superficial laminae (I, II-outer, II-inner, and III). Large neurons in laminae IV and $V$ expressed mainly NR1, GluR-C, and to lesser extents the GluR-B, GluR-D, and NR2D genes. Lamina I contained occasional cells expressing the GluR-5 gene, whereas GluR-7 mRNA was present in scattered cells in all superficial laminae. In motor neurons, GluR-B Flip, -C Flip, -D Flip, and NR1 mRNAs were expressed heavily, and those of NR2D and KA-1 weakly. Possibly connected to the RNA editing mechanism, GluR-B was the only subunit whose RNA was concentrated in motor neuron cell nuclei in addition to the cytoplasm. $\delta-1$ and -2 mRNAs were found at low levels throughout the gray matter. NR2A, NR2B, and GluR-6 mRNAs were undetectable. For the periaqueductal gray, prominent mRNAs were GluR-A, -B, and NR1. An en passant observation concerned high levels of NR2C mRNA in the pineal gland.
\end{abstract}

[Key words: glutamate receptor, NMDA, AMPA, kainate, mRNA, in situ hybridization, spinal cord, dorsal horn, motor neuron, central gray, pineal gland]

The spinal cord was one of the first CNS areas in which it was demonstrated that amino acids such as glutamate depolarize neurons (Curtis et al., 1959; reviewed by Willis and Coggeshall, 1991). It is now established that the PNS fibers transmitting mechanical, thermal, and chemical stimuli into the dorsal horn

\footnotetext{
Received Feb. 1, 1993; revised May 17, 1993; accepted May 26, 1993.

Correspondence should be addressed to Dr. T. R. Tölle, Max-Planck-Institut für Psychiatrie, Klinisches Institut, Klinische Neuropharmakologie, Kraepelinstrasse 2, 8000 Munich 40, Germany.

a Present address: Laboratory of Molecular Biology, MRC Center, Hills Road, Cambridge, England.

Copyright (C) 1993 Society for Neuroscience $0270-6474 / 93 / 135009-20 \$ 05.00 / 0$
}

of the spinal cord use either glutamate or aspartate as principal excitatory transmitters (e.g., Zieglgänsberger and Puil, 1973; Jessel et al., 1986; Sillar and Roberts, 1988; Gerber and Randic, 1989; Morris, 1989; Dougherty et al., 1992; reviewed by Headley and Grillner, 1990; Willis and Coggeshall, 1991; Nelson and Sur, 1992). Within the deeper laminae of the spinal cord, there are also many neurons that respond to excitatory amino acids (EAAs) via ligand-gated channels (Gerber and Randic, 1989; Burke, 1990; Smith et al., 1991; Willis and Coggeshall, 1991).

Three EAA ionotropic receptor subtypes are classified on the basis of their selectivity to synthetic agonists as (1) NMDA, (2) high-affinity $\alpha$-amino-3-hydroxy-5-methyl-isoxazole-4-propionate (AMPA)/low-affinity kainate, and (3) high-affinity kainate receptors (reviewed by Young and Fagg, 1990; Monaghan and Anderson, 1991; Gasic and Hollmann, 1992; Sommer and Seeburg, 1992). Autoradiographic studies indicate the presence of all three binding sites in the mammalian spinal cord (Monaghan and Cotman, 1982, 1985; Jansen et al., 1990; Mitchell and Anderson, 1991; Shaw et al., 1991; Kalb et al., 1992), but because of a lack of selective antagonists, electrophysiological studies have been confined to studies of NMDA versus non-NMDA ionotropic receptors. Molecular cloning studies have demonstrated that these EAA receptor subtypes are heterooligomeric assemblies of subunits (reviewed by Nakanishi, 1992; Sommer and Seeburg, 1992; Wisden and Seeburg, 1993a). The exact subunit composition of any channel type is not known, but varies in a brain region-specific manner. NMDA receptors comprising the NR1 and NR2A to -2D subunits are believed to exist in vivo as NR1/NR2 heteromerics (Moriyoshi et al., 1991; Ikcda ct al., 1992; Kutsuwada et al., 1992; Meguro et al., 1992; Monyer et al., 1992). They are distinguished by their voltagedependent $\mathrm{Mg}^{2+}$ block, slow gating kinetics, and permeability to $\mathrm{Ca}^{2+}$ (reviewed by Bekkers and Stevens, 1990; Moriyoshi et al., 1991; Monyer et al., 1992). High-affinity AMPA/low-affinity kainate receptors (consisting of the GluR-A to -D, GluR 1 to -4 subunits) often colocalize with NMDA receptors in the same synapse and mediate "general purpose" fast excitatory transmission (Bekkers and Stevens, 1989; Hollmann et al., 1989; Boulter et al., 1990; Keinänen et al., 1990; Nakanishi et al., 1990; Jones and Baughman, 1991). Each of the GluR-A to -D subunits exists as a Flip and Flop variant (Sommer et al., 1990). The Flip and Flop domains are mutually exclusive cassettes specified by alternative splicing, and confer different response characteristics to applied AMPA and glutamate (Sommer et al., 1990; Jonas and Sakmann, 1992). Recombinant AMPA receptor configurations lacking the GluR-B subunit are permeable to $\mathrm{Ca}^{2+}$ (Hollmann et al., 1991; Burnashev et al., 1992a), as is the 
case in vivo on a minority of neuronal and glial cell types where the GluR-B subunit is not expressed (Pruss et al., 1991; Burnashev et al., 1992b; Müller et al., 1992). High-affinity kainate receptors can be constructed from heteromeric and/or homomeric combinations from two classes of subunits: KA-1 and -2 and GluR-5, -6, and -7 (Egebjerg et al., 1991; Werner et al., 1991; Herb et al., 1992; Sakimura et al., 1992; Sommer et al., 1992). In contrast to AMPA/low-affinity kainate receptors, highaffinity kainate receptors have currents that desensitize rapidly in the presence of kainate. The physiological function of highaffinity kainate receptors is not understood, and it is likely that members of this subfamily are mainly located on presynaptic terminals and dendrites (e.g., Good et al., 1992). Additionally, high-affinity kainate receptors, particularly those containing the GluR-5 subunit, are synthesized in dorsal root ganglion cells (Bettler et al., 1990; Headley and Grillner, 1990; Huettner, 1990; Sommer et al., 1992), and may function as presynaptic autoreceptors on primary afferent terminals (Headly and Grillner, 1990). The $\delta-1$ and $\delta-2$ subunits are in the same gene family, but currently cannot be assigned to a particular EAA receptor subunit type (Yamazaki et al., 1992; Lomeli et al., 1993).

The activation of EAA reccptors in the spinal cord and higher brain nuclei is important for both general "housekeeping" and pathological functions. Non-NMDA receptor activation is essential for fast excitatory transmission between many spinal neuronal cell types, as in other areas of the CNS (reviewed by Burke, 1990; Willis and Coggeshall, 1991). For example, the monosynaptic stretch reflex involving the direct action of primary afferents on motor neurons utilizes fast EPSPs generated by the activation of AMPA/low-affinity kainate receptors (Burke, 1990; Di-Prisco et al., 1990; Long ct al., 1990; Jiang ct al., 1991), as does neurotransmission of inspiratory drive from nuclei in the brainstem synapsing directly onto motor neurons (McCrimmon et al., 1989). The special integrative properties of NMDA-gated channels (voltage-dependent $\mathrm{Mg}^{2+}$ block, and prolonged open time) are required for generating bursting patterns in the spinal cord (Grillner and Matsushima, 1991). Such burst properties are utilized by pattern-generating circuits involved in the execution of regular movements (Grillner and Matsushima, 1991).

At a pathological level, regulation of the voltage-dependent $\mathrm{Mg}^{2+}$ ion block of NMDA receptors is in part responsible for the central sensitization of pain perception (Davies and Lodge, 1987; Chen and Huang, 1991; Woolf and Thompson, 1991; reviewed by Stevens, 1992). Electrophysiological studies have demonstrated that repeated stimulation of pain fibers gives progressively larger responses in the central pain-reporting neurons to which they project-a phenomenon termed "wind-up." NMDA receptors directly participate in this wind-up of dorsal horn neurons (Davies and Lodge, 1987; Schouenberg and Dickenson, 1988; Tölle et al., 1989; Woolf and Thompson, 1991). The sensitized neurons respond to non-noxious stimuli to which they would not normally respond-a process termed hyperalgesia (reviewed by Simone, 1992).

The mesencephalic central gray/periaqueductal gray (PAG), which consists of a dense layer of neurons surrounding the cerebral aqueduct, and the reticular formation, which consists of a diffuse network of nuclei, are both important relay/processing centers for ascending and descending sensory/motor pathways to the spinal cord (Fields and Basbaum, 1978; Beitz, 1982; Mantyh and Peschanski, 1982; Basbaum and Fields, 1984; Andrezik and Beitz, 1985; Jordan at al., 1992; for review, see 
Zieglgänsberger, 1986; Willis, 1988). Both these areas receive nociceptive input from the periphery. Intracerebral administration of EAAs to discrete regions of the brainstem results in spontaneous algogenic behavior with sensitive sites largely limited to the mesencephalic PAG (Jensen and Yaksh, 1992). Besides sensory information processing, these sites represent important relays for the initiation of locomotion in vivo and in vitro (Cazalets et al., 1992).

Until now, there have been no studies reporting on ionotropic EAA receptor subunit gene expression in the spinal cord. In this article, using in situ hybridization with subunit specific oligonucleotides, we have mapped the expression of all 16 currently known genes in the ligand-gated EAA receptor superfamily.

\section{Materials and Methods}

Segments of adult female Wistar rat lumbar spinal cord $(n=5)$ were dissected from freshly decapitated non-perfusion-fixed animals. Blocks of spinal cord were frozen on dry ice. Sections $(14 \mu \mathrm{m})$ cut on a cryostat at $-20^{\circ} \mathrm{C}$ were processed for in situ hybridization as described previously (Wisden et al., 1991b). Oligonucleotides (36mers and 42-45mers) were labeled with $\alpha-{ }^{35} \mathrm{~S}-\mathrm{dATP}(1200 \mathrm{Ci} / \mathrm{mmol}$; New England Nuclear) using terminal transferase (Boehringer Mannheim) and a 30:1 molar ratio of dATP : oligonucleotide. Sections were hybridized in $50 \%$ formamide, $4 \times$ saline-sodium citrate (SSC), $10 \%$ dextran sulfate at $42^{\circ} \mathrm{C}$ for $12 \mathrm{hr}$, and were washed in $1 \times \mathrm{SSC}$ at $55^{\circ} \mathrm{C}$. Sections were then either exposed to Kodak XAR-5 film (for 4 weeks) or dipped in Ilford K5 emulsion (for 8 weeks). After development, sections were counterstained with thionin.

Oligonucleotides specific for the rat subunit mRNAs were as used previously. The AMPA-selective oligonucleotides (GluR-A to GluR-D) were described by Keinänen et al. (1990). The Flip and Flop splice variants of the GluR-A to -D subunit genes were identical to those used by Sommer et al. (1990). The high-affinity kainate oligonucleotides (KA$1,-2$, GluR-5, -6, and -7) were described by Wisden and Seeburg (1993b); The $\delta-1$ and -2 probes were as described by Lomeli et al. (1993); the NMDA receptor subunit oligonucleotides were as used by Monyer et al. (1992). The NR2D oligonucleotide was 5'-CGTGGCCAGGCTTCGGTTATAGCCCACAGGACTGAGGTACTC-3' constructed to the region between the putative first and second membranespanning regions (Ikeda et al., 1992; H. Monyer and P. H. Seeburg, unpublished observations). Controls for specificity included incubating sections with a 100 -fold excess of unlabeled probe with the corresponding ${ }^{35} \mathrm{~S}$-labeled probe.

To minimize cross-hybridization to very closely related sequences, the shorter (36mer) Flip and Flop probes were still hybridized and washed with identical conditions to those used for the longer (pan) probes, with the result that they gave much weaker autoradiographic images. Thus, it was not possible to compare signal intensities directly between the pan and Flip/Flop probes.

\section{Results}

The results are semiquantitatively summarized in Tables 1 and 2. The anatomy of the spinal cord is presented in Figure 1 in

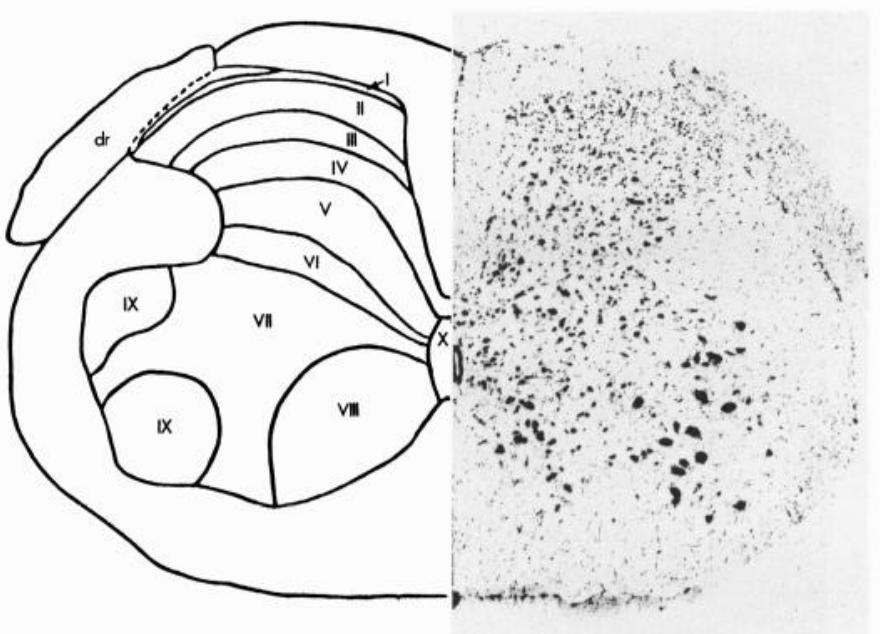

Figure 1. Schematic and matching Nissl-counterstained slice of the adult rat lumbar spinal cord. The figure shows the attached dorsal root $(d r)$ and the Rexed laminae $(I-X)$. Modified from Brichta and Grant (1985).

order to enable the reader to orientate the results with the different numbered laminae mentioned below.

Distribution of AMPA receptor subunit mRNAs (GluR-A to $-D$ including the Flip and Flop splice variants) in lumbar spinal cord

As assessed using the pan oligonucleotide probes, all four highaffinity AMPA receptor subunit mRNAs are present in the spinal cord, although they exhibit pronounced differential distributions (Fig. 2, Table 1). In laminae I and II of the dorsal horn, GluR-A and -B transcripts are the most abundant (Fig. 2a,b). While the GluR-A gene is preferentially expressed in neurons of laminae I and II-outer (II-o), the GluR-B mRNA is more evenly expressed throughout all superficial laminae, that is, I, II-o, II-inner (II-i), and III, revealing a substantial mismatch between these two subunits. This is reflected at the cellular level (Figs. $3 a, b, 4 a, b$ ). In fact, GluR-B is the only prominent AMPAselective subunit in lamina III (Fig. $4 b$ ). The dorsal horn pan GluR-A signal consists of both Flip and Flop components (Fig. 6 , Table 2). In contrast, most of the dorsal horn GluR-B signal is derived from GluR-B Flip (Fig. 6). The mRNAs encoding GluR-C and -D can also be detected in the dorsal horn, with the GluR-C gene being moderately expressed in a few isolated cells (Fig. $4 c$ ) and that of GluR-D being expressed at low levels in some cells in laminae I and II (Fig. 4d). The GluR-C gene

Table 2. Summary of the distribution of the Flip and Flop GluR-A to -D splice variants in rat lumbar spinal cord

\begin{tabular}{|c|c|c|c|c|c|c|c|c|}
\hline & \multicolumn{2}{|c|}{ GluR-A } & \multicolumn{2}{|c|}{ GluR-B } & \multicolumn{2}{|c|}{ GluR-C } & \multicolumn{2}{|c|}{ GluR-D } \\
\hline & Flip & Flop & Flip & Flop & Flip & Flop & Flip & Flop \\
\hline \multicolumn{9}{|l|}{ Dorsal horn } \\
\hline Laminae I-III & + & ++ & +++ & + & + & 0 & $(+)$ & $(+)$ \\
\hline Laminae IV-VI & $(+)$ & + & + & $(+)$ & + & + & $(+)$ & $(+)$ \\
\hline Lamina $\mathrm{X}$ & $(+)$ & + & + & + & $(+)$ & $(+)$ & $(+)$ & $(+)$ \\
\hline \multicolumn{9}{|l|}{ Ventral horn } \\
\hline Laminae VII-VIII & $(+)$ & + & + & $(+)$ & $(+)$ & $(+)$ & $(+)$ & $(+)$ \\
\hline Motor neurons & $(+)$ & $(+)$ & ++ & + & ++ & ++ & +++ & 0 \\
\hline
\end{tabular}

0 , Not detectable; $(+)$, weakly detectable; + , detectable; ++ , quite abundant; +++ , very abundant. 

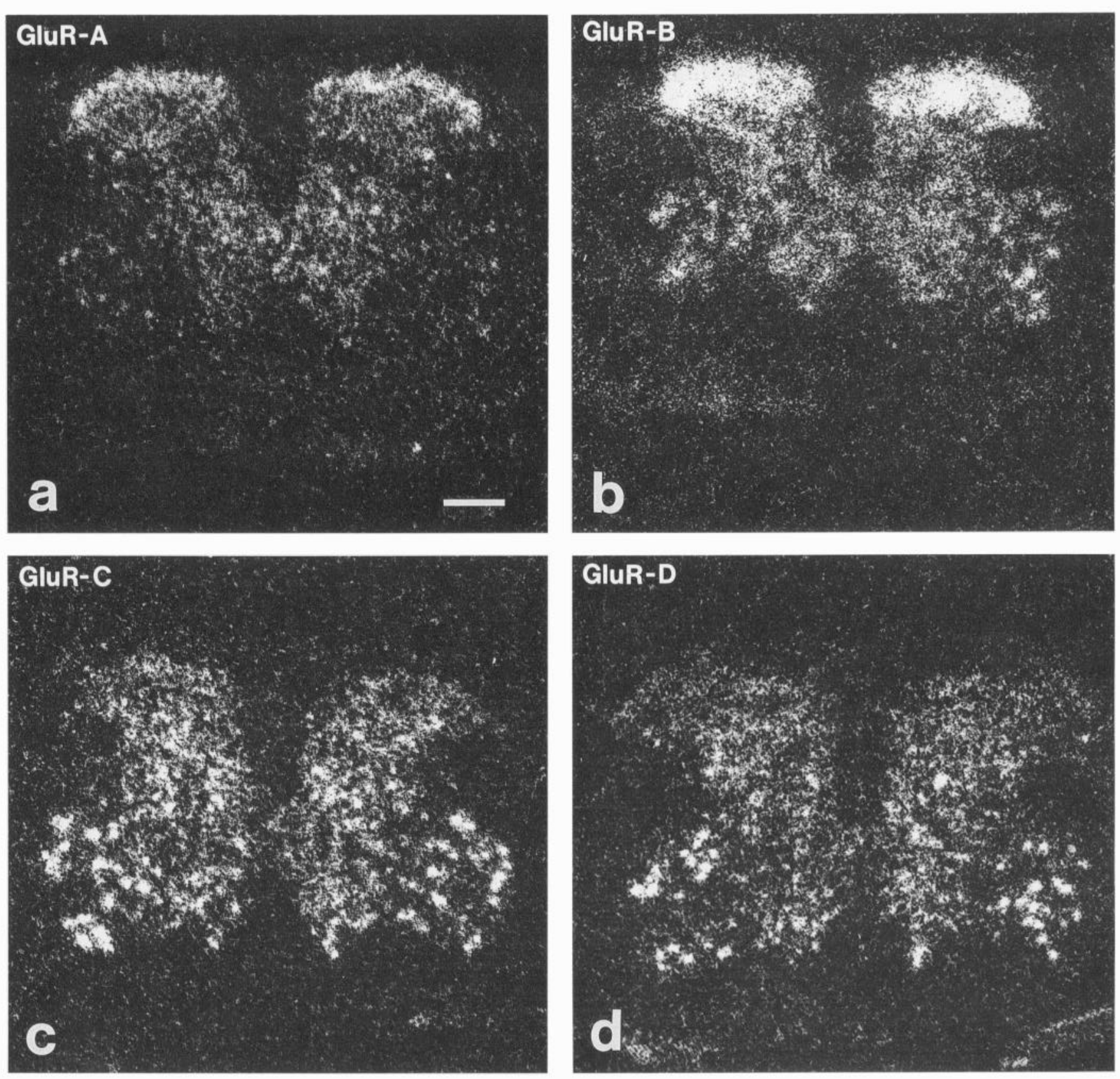

Figure 2. X-ray film autoradiographs illustrating the distribution of high-affinity AMPA receptor subunit transcripts $(G l u R-A,-B,-C$, and $-D)$ in rat lumbar spinal cord. $a$, GluR-A; $b$, GluR-B; $c$, GluR-C; $d$, GluR-D. White areas represent high densities of mRNA, for example, in the dorsal horn $(a, b)$ or in motor neurons of the ventral horn $(c, d)$. Scale bar, $300 \mu \mathrm{m}$.

is the only member of the high-affinity AMPA series to be expressed prominently in large neurons in laminae IV and $\mathrm{V}$ (Fig. 2c). There is weaker expression of the GluR-B and GluR-D genes in these large cells (Fig. $2 d$ ).

In the ventral horn, GluR-B, -C, and -D mRNAs are present in motor neurons, with the GluR-C and -D subunit genes being the most expressed (Fig. 2c,d). The GluR-A Flop mRNA is expressed very weakly in motor neurons (Figs. $2 a, 5 a, 6)$. Emulsion autoradiography confirms the heavy expression of the $-\mathrm{C}$ and -D subunits in these cells (Fig. $5 c, d$ ). The pan GluR-C motor neuron signal is probably generated from a combination of both the Flip and Fiop splice forms Fig. 6, Table 2). In contrast, the pan GluR-D motor neuron signal seems to be derived exclusively from GluR-D Flip (Fig. 6). Interestingly, the majority of silver grains obtained with the pan GluR-B probe (presumably derived from GluR-B Flip; Fig. 6) are located mainly over the motor neuron cell nucleus, with many fewer grains over the cytoplasm (Fig. $5 b$ ). This observation is found to be true for all motor neurons examined in any section. Conversely, the $-\mathrm{C}$ and -D mRNAs are always abundant in the cytoplasm as well as the nucleus. Besides their strong expression in motor neurons, AMPA-selective subunit mRNAs are found in laminae VII and VIII, and in the area surrounding the central canal (lamina X) (see Fig. 2). 



Figure 3. Low-power dark-field optics illustrating cells expressing high-affinity AMPA receptor subunit transcripts in the substantia gelatinosa (dorsal horn) area of the spinal cord. $a$, GluR-A; $b$, GluR-B; $c$, GluR-C; $d$, GluR-D. Broken lines are derived from camera lucida drawings of each individual Nissl-stained section and delineate the boundaries of the white and gray matter. Rexed laminae are labeled according to Brichta and Grant (1985). Scale bar, $100 \mu \mathrm{m}$.

Distribution of high-affinity kainate and $\delta$-subunit mRNAs (GluR-5, -6, -7, KA-1,-2, $\delta-1,-2)$ in lumbar spinal cord

Levels of the high-affinity kainate receptor transcripts are much lower than those of the AMPA receptor transcripts. The GluR-6 gene is not expressed at all in the spinal cord, although as a positive control, the same probe detects signals in the hippocampus (see Fig. $11 \mathrm{~g}$ ). At the level of $\mathrm{x}$-ray film, KA-1 mRNA is marginally the most prominent member of this subclass in motor neurons (Fig. 7a), whereas KA-2 mRNA is the most abundant in the dorsal horn (Fig. 7 b). Celllular resolution reveals small cells expressing the KA-2 gene in the substantia gelatinosa, with few grains over each cell (Fig. 8d), and a moderate signal for KA-1 in motor neurons (Fig. 8c). In contrast to the situation observed for the AMPA receptor subunit mRNAs, many cells are not labeled with the KA-2 probe. Thus, the KA-2 gene is likely to be expressed in a subpopulation of cells that express the AMPA-selective subunits. The GluR-5 and -7 probes give very low signals on $\mathrm{x}$-ray film (Fig. $7 c, d$ ). However, there are small numbers of positive cells expressing these genes in the substantia gelatinosa. The GluR-5 subunit gene expression is more restricted to occasional cells in lamina I (Fig. 8a), whereas GluR-7 is found in occasional cells in all superficial laminae of the dorsal horn (Fig. 8b). Emulsion autoradiography with the GluR- 5 probe reveals a few silver grains specifically located over a small number of motor neurons (not shown). The $\delta-1$ and -2 mRNAs are present in weak diffuse levels throughout the gray matter, with a slightly more pronounced expression in the substantia gelatinosa for the $\delta-2$ subunit (Fig. 7e,f). Both the $\delta-1$ and -2 probes give weak but detectable signals over motor neurons.

Distribution of NMDA receptor subunit mRNAs (NRI, NR2A to NR2D) in lumbar spinal cord

Of the NMDA receptor subunit mRNAs, only those of the NR1, NR2C, and NR2D genes are detectable. However, the NR1 mRNA is considerably more abundant than the others (Fig. 9), being found in virtually every neuron, as confirmed by cellular resolution. The NRI gene is expressed in many cells both in the substantia gelatinosa (Fig. 10a) and in motor neurons (Fig. $10 d$ ). The NR2C mRNA is weakly present in the substantia gelatinosa and the NR2D is present at low levels everywhere in the gray matter, but is slightly concentrated in the substantia gelatinosa and lamina $X$ (central canal area) (Fig. 9b,c). The NR2D gene is also expressed at low levels in motor neurons (Fig. 10e). The NR2C mRNA can be detected in occasional cells in the substantia gelatinosa laminae I and II (Fig. 10b). The NR2D-positive cells are more numerous in the substantia gelatinosa than those of NR2C (Fig. 10b,c), although these must be subsets of the NR1-positive neurons.

\section{Expression of glutamate receptors in the PAG}

We analyzed the expression of the ionotropic glutamate receptor genes in serial sections of the PAG from caudal (at level of the pineal gland and inferior colliculus) to rostral (at level of the hippocampus) (Figs. 11-13). Serial sections of the PAG are presented counterstained with thionin in order to enable the reader to orientate the results with the different anatomical structures 

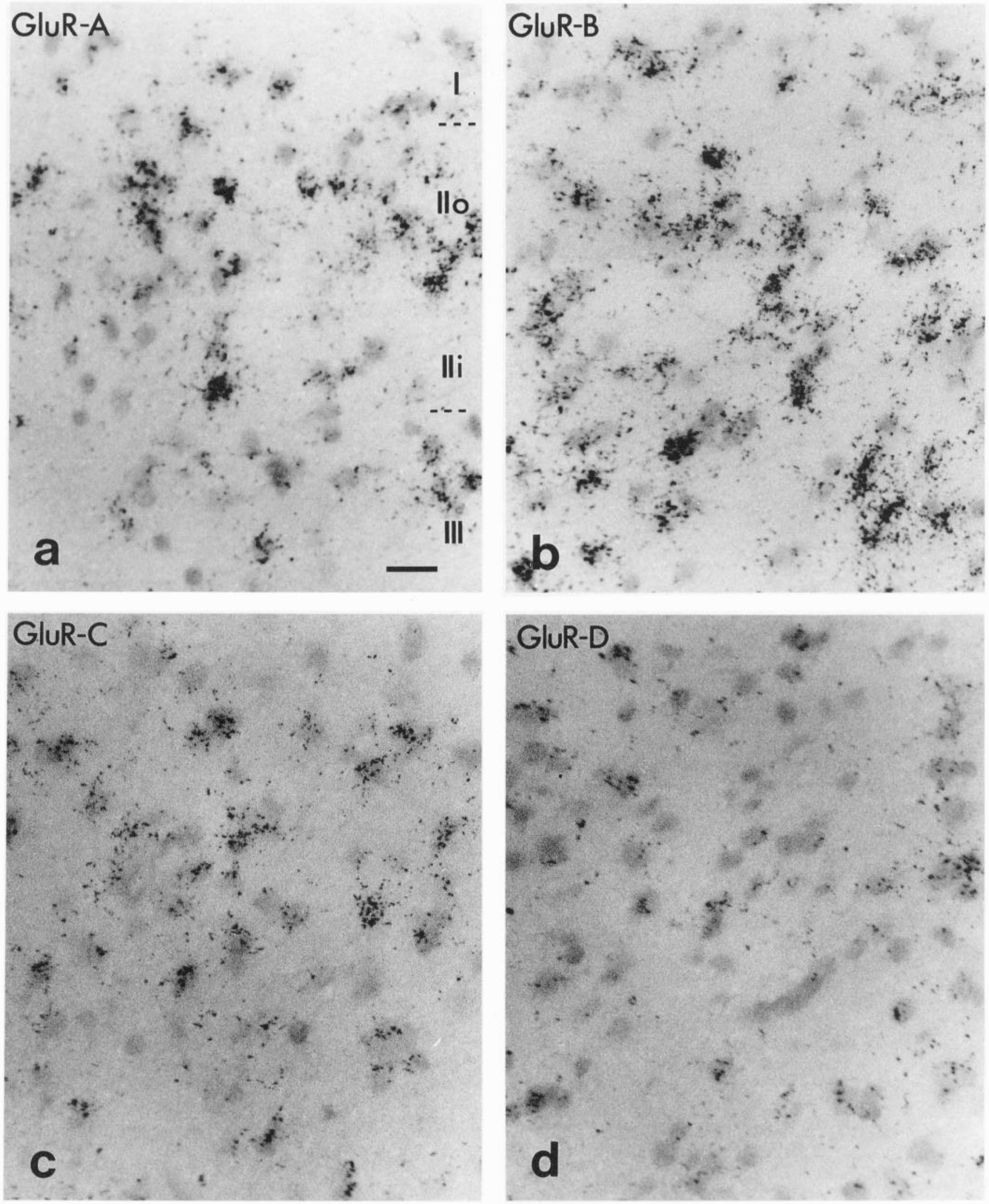

Figure 4. High-power bright-field photomicrographs showing expressing of the GluR-A $(a)$, GluR-B $(b)$, GluR-C $(c)$, and GluR-D genes $(d)$ in the substantia gelatinosa area. GluR-A is most prominently expressed in laminae $I$ and $I I-O$, while GluR-B is more evenly distributed in neurons of all laminae of the superficial dorsal horn. Roman numerals in $a$ indicate Rexed laminae. Scale bar, $20 \mu \mathrm{m}$. 

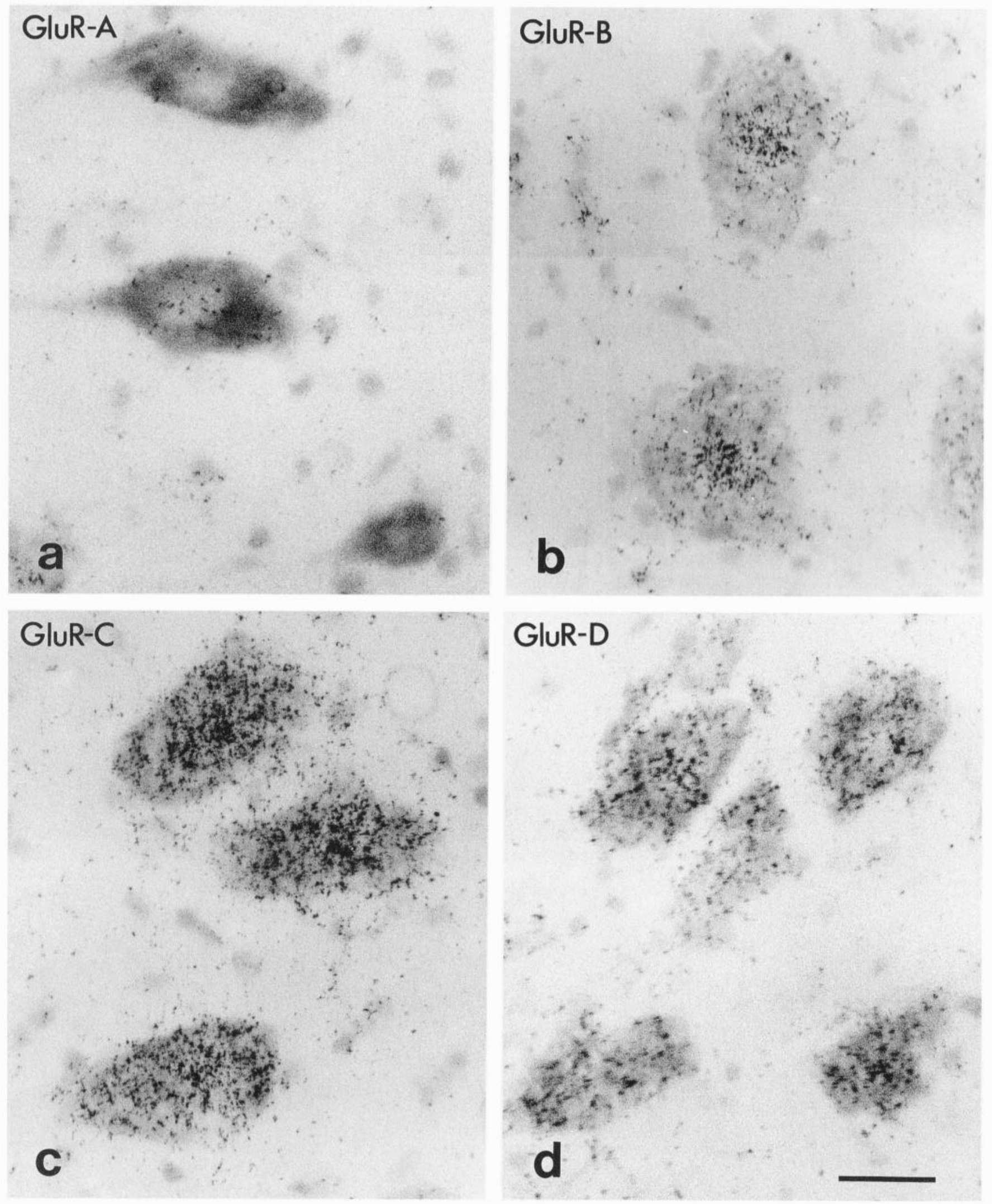

Figure 5. High-power bright-field photomicrographs showing the expression of the high-affinity AMPA receptor genes in motor neurons. $a$, GluRA; $b$, GluR-B; $c$, GluR-C; $d$, GluR-D. GluR-B, -C, and -D subunits genes are the most expressed. The majority of silver grains obtained with the GluR-B probe are located mainly over the motor neuron cell nucleus, with fewer grains over the cytoplasm. Scale bar, $25 \mu \mathrm{m}$. 

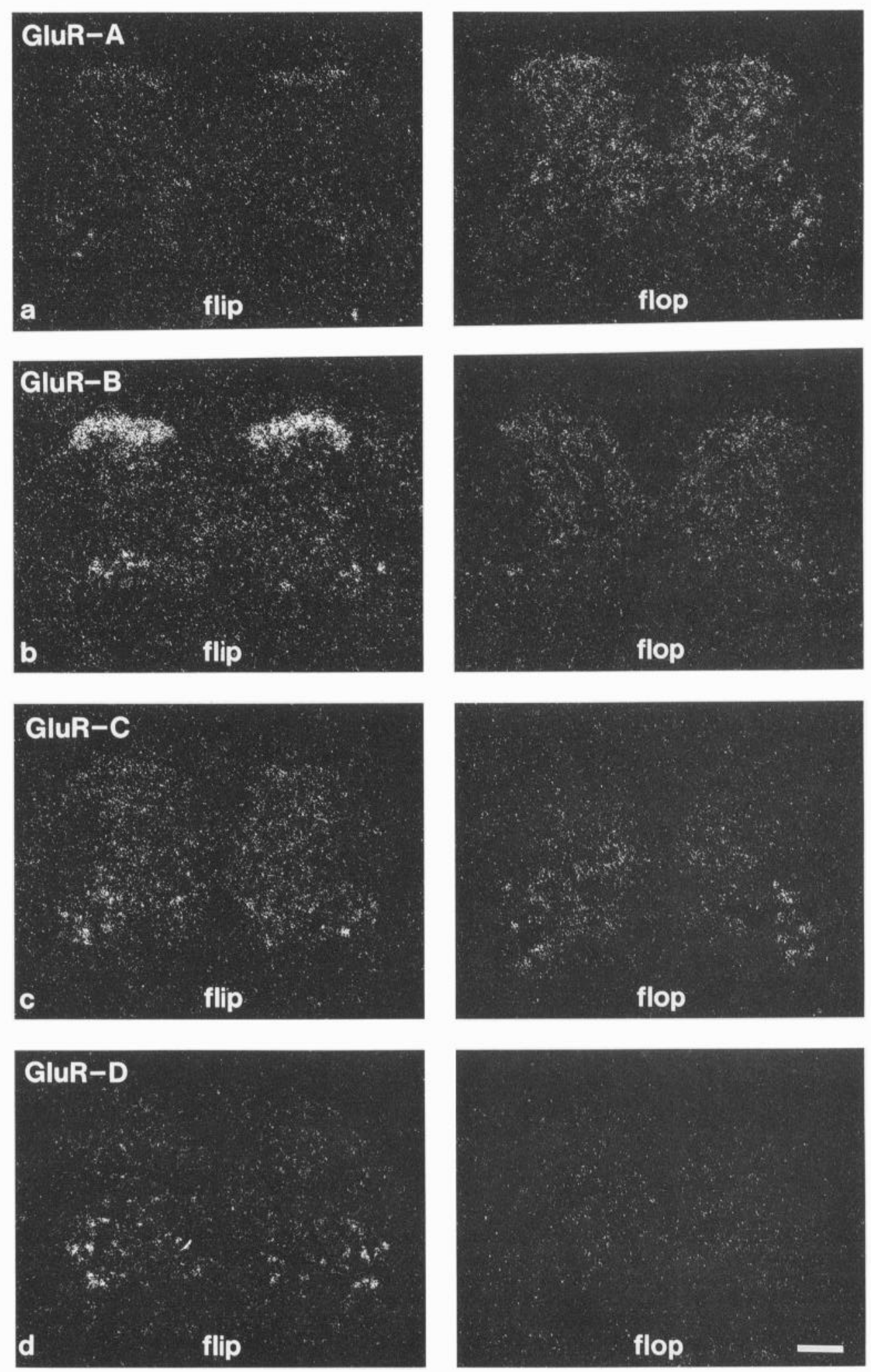

Figure 6. X-ray film autoradiographs illustrating distribution of the Flip and Flop mRNAs in rat lumbar spinal cord. Row $a$, GluR-A Flip and Flop; row $b$. GluR-B Flip and Flop; row c, GluR-C Flip and Flop; row d, GluR-D Flip and Flop. Scale bar, $300 \mu \mathrm{m}$.

(Fig. 13f). The autoradiographs generated of the consecutive sections through these areas of the midbrain further highlight the heterogeneity of ionotropic EAA receptor expression in the CNS.

All four high-affinity AMPA receptor subunit mRNAs are present in the central gray (Fig. 11a-d), with GluR-A and -B transcripts being the most abundant (Fig. 1 $1 a, b$ ). There are no overt differences in AMPA subunit expression between rostral and caudal areas of the central gray. The only representatives of the high-affinity subunit series in the PAG are KA-1, -2 (Fig. $12 a, b$ ), and GluR-7 (Fig. 11e). The GluR-5 and -6 subunit mRNAs are absent, although specific signals for these mRNAs 

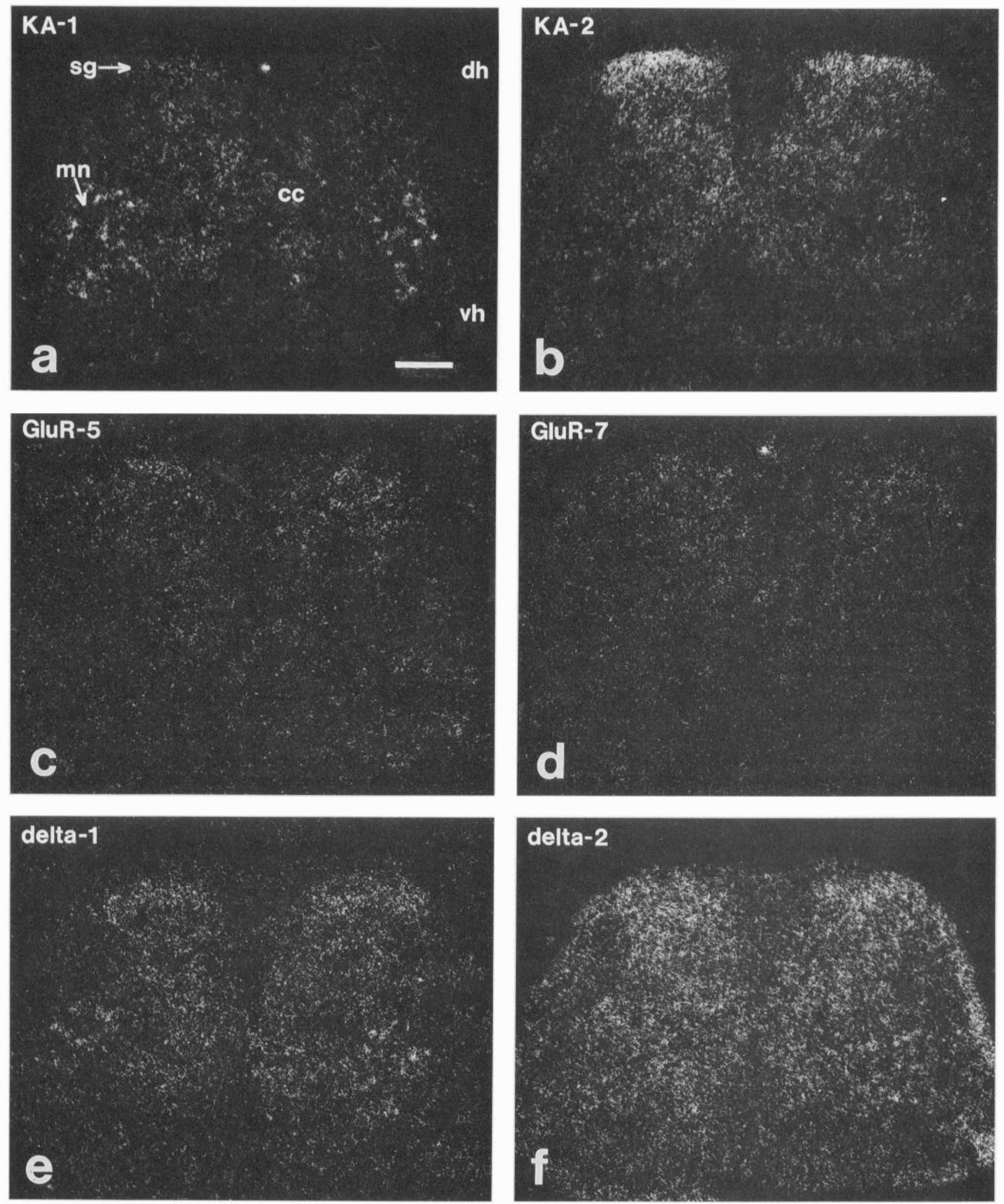

Figure 7. Macroscopic x-ray film autoradiographs illustrating the expression of high-affinity kainate receptor subunits and $\delta$-subunits in rat lumbar spinal cord. $a$, KA-1; $b, \mathrm{KA}-2 ; c$, GluR-5; $d$, GluR-7; $e, \delta-1 ; f, \delta-2$. KA-1 is marginally the most prominent member of this subclass in motor neurons $(a)$, whereas KA-2 is most abundant in the dorsal horn $(b)$. GluR-5, -7 and $\delta-1,-2$ give low signals on $\mathrm{x}$-ray film. dh, dorsal horn; vh, ventral horn; $s g$, substantia gelatinosa; $m n$, motor neurons; $c c$, central canal. Scale bar, $300 \mu \mathrm{m}$. 

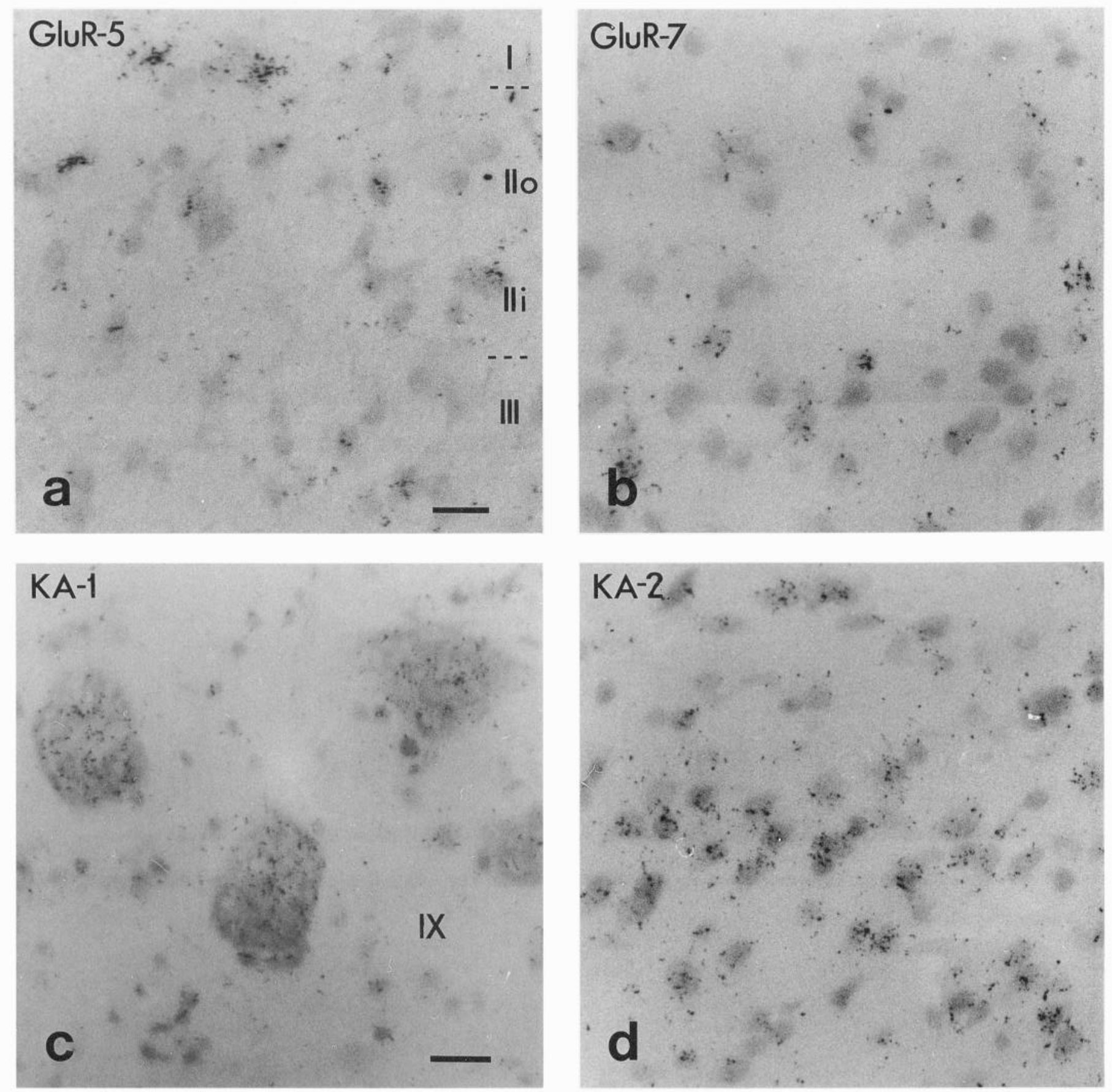

Figure 8. High-power bright-field photomicrographs showing cellular resolution of various high-affinity kainate receptors in spinal cord. GluR-5 subunit gene was restricted to occasional cells in lamina I $(a)$, whereas GluR-7 was found with few silver grains in numerous cells of all laminae (b). $c$, KA-1 is almost restricted to motor neurons; $d$, KA-2 is abundant in the dorsal horn. Roman numerals indicate Rexed laminae. Scale bars, $20 \mu \mathrm{m}$.

are detected elsewhere on the sections, for example, superior colliculi for GluR-5 and hippocampus for GluR-6, thus confirming that the probes are not defective (Fig. $11 f, g$ ).

Considering the levels of NMDA receptor subunit transcripts in the PAG, NR1 mRNA is massively expressed relative to the members of the NR2 series. For the NR1 subunit, there is no difference in gene expression between caudal to rostral areas of the PAG (Fig. 13a, left to right). The NR2A and NR2B subunit mRNAs are not detectable, and the NR2C gene is poorly expressed in the PAG (Fig. 13b-d). However, on the same section, the NR2C probe detects high levels of mRNA in the pineal gland and cerebellar granule cells (Fig. 13d). As noted previously (Wisden and Seeburg, 1993) KA-2 mRNA is also found in the pineal gland (Fig. 12b, left). The NR2D gene is weakly expressed, at approximately the same intensity as in the spinal cord (Fig. $12 e$ ).

\section{Discussion}

We have examined the expression of the 16 genes whose encoded polypeptides collectively comprise subunits for the NMDA 
(NR1, NR2A to NR2D), AMPA/low-affinity kainate (GluR-A to -D), and high-affinity kainate (KA-1, -2, GluR-5 to -7) receptors as well as two orphan subunits $(\delta-1$ and -2$)$ in the spinal cord and the PAG. As in other parts of the CNS (e.g., Bettler et al., 1990, 1992; Keinänen et al., 1990; Sommer et al., 1990; Monyer et al., 1992; Wisden and Seeburg, 1993b), EAA receptor subunit transcripts show differential distributions within the gray matter of the two structures (summarized in Tables 1 and 2). In both sites their expression is of interest because of the identified role of EAA receptors in relation to sensory transmission, including pain, as well as their general "housekeeping" contribution to local circuitry. It is believed that non-NMDA (AMPA/low-affinity kainate) receptors mediate the responses of dorsal horn neurons to monosynaptic inputs while NMDA receptors mediate responses to polysynaptic inputs involving interneurons (see Willis and Coggeshall, 1991; Dougherty et al., 1992, and references therein). Further, NMDA receptors are implicated in the production of the enhanced responsiveness of dorsal horn neurons following peripheral injury (e.g., Haley et al., 1990; Chen and Huang, 1991; Woolf and Thompson, 1991; Dougherty et al., 1992; Ren et al., 1992; reviewed by Stevens, 1992). Neurons originating in the PAG serve to suppress pain by controlling the input transition from primary afferents to spinofugally projecting dorsal horn neurons, and are also excited by EAAs.

\section{AMPA receptor heterogeneity}

Based on our in situ hybridization results, the postsynaptic AMPA/low-affinity kainate receptor subunit composition in the spinal cord probably varies with the type of afferent input. For example, Ia afferents originating from receptors on muscle spindles synapse directly onto motor neurons in the ventral horn to generate the EPSPs of the simple stretch reflex arc (Burke, 1990). The postsynaptic AMPA/low-affinity kainate receptors activated on these motor neurons by Ia terminals and also the excitatory terminals from interneurons onto motor neurons are likely to be of composition GluR-C Flip-Flop/GluR-D Flip or GluRB/GluR-C/GluR-D Flip. However, in the dorsal horn (laminae I, II-o), afferent fibers probably activate AMPA/low-affinity kainate receptors mainly of composition GluR-A/GluR-B Flip, with only a minor population of receptors that contain the GluR-C and GluR-D subunits. In laminae II-i and III, where there is very little GluR-A mRNA, homomeric GluR-B AMPA/ low-affinity kainate receptors may predominate. Large neurons in laminae IV and V may principally express GluR-C/GluR-D heteromerics. From their anatomical location, these GluR-C/ GluR-D-expressing cells may correspond to neurons associated with the spinothalamic and spinoreticular tracts (Willis et al., 1974; Giesler et al., 1979; Chaouch et al., 1983; for review see Willis and Coggeshall, 1991). Many lamina IV and V neurons send their dorsal dendrites into laminae I and II, and can thus receive a direct primary afferent input from fibers entering the superficial laminae. Thus, a particular primary afferent fiber terminating in laminae I and II could activate two types of AMPA/low-affinity kainate receptor: the GluR-A/GluR-B receptors on laminae I/II neurons and the GluR-C/GluR-D receptors on dendrites from deeper neurons.

These varying subunit compositions have implications for the properties of ion flow that occurs in response to agonist activation. AMPA receptors containing either the Flip or Flop forms or a combination of both subunit types exhibit different functional properties, although the physiological significance of
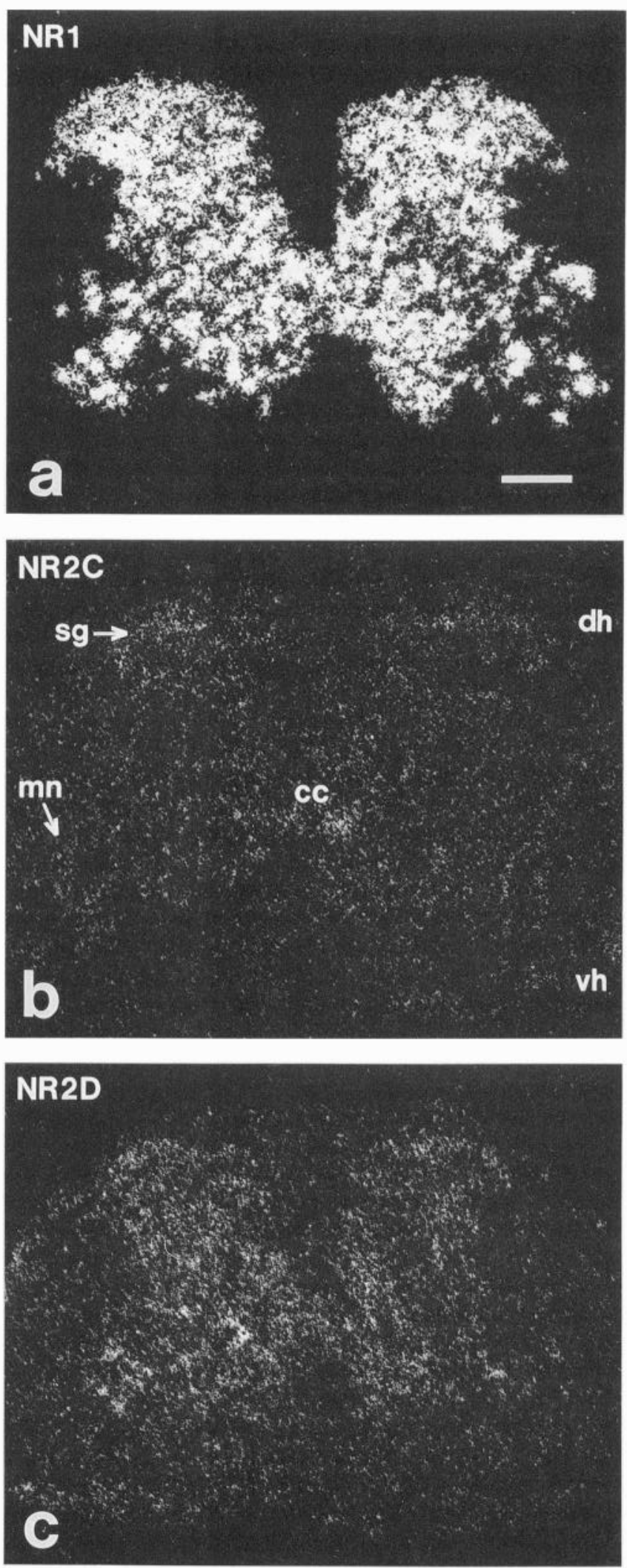

Figure 9. X-ray autoradiographs showing NMDA receptor subunit gene expression in the lumbar spinal cord. $a$, NR $1 ; b, \mathrm{NR} 2 \mathrm{C} ; c, \mathrm{NR} 2 \mathrm{D}$. The NR1 mRNA is the most abundant in the whole gray matter of the dorsal and ventral horn. $d h$, dorsal horn; $v h$, ventral horn; sg, substantia gelatinosa; $m n$, motor neurons; $c c$, central canal. Scale bar, $300 \mu \mathrm{m}$. 

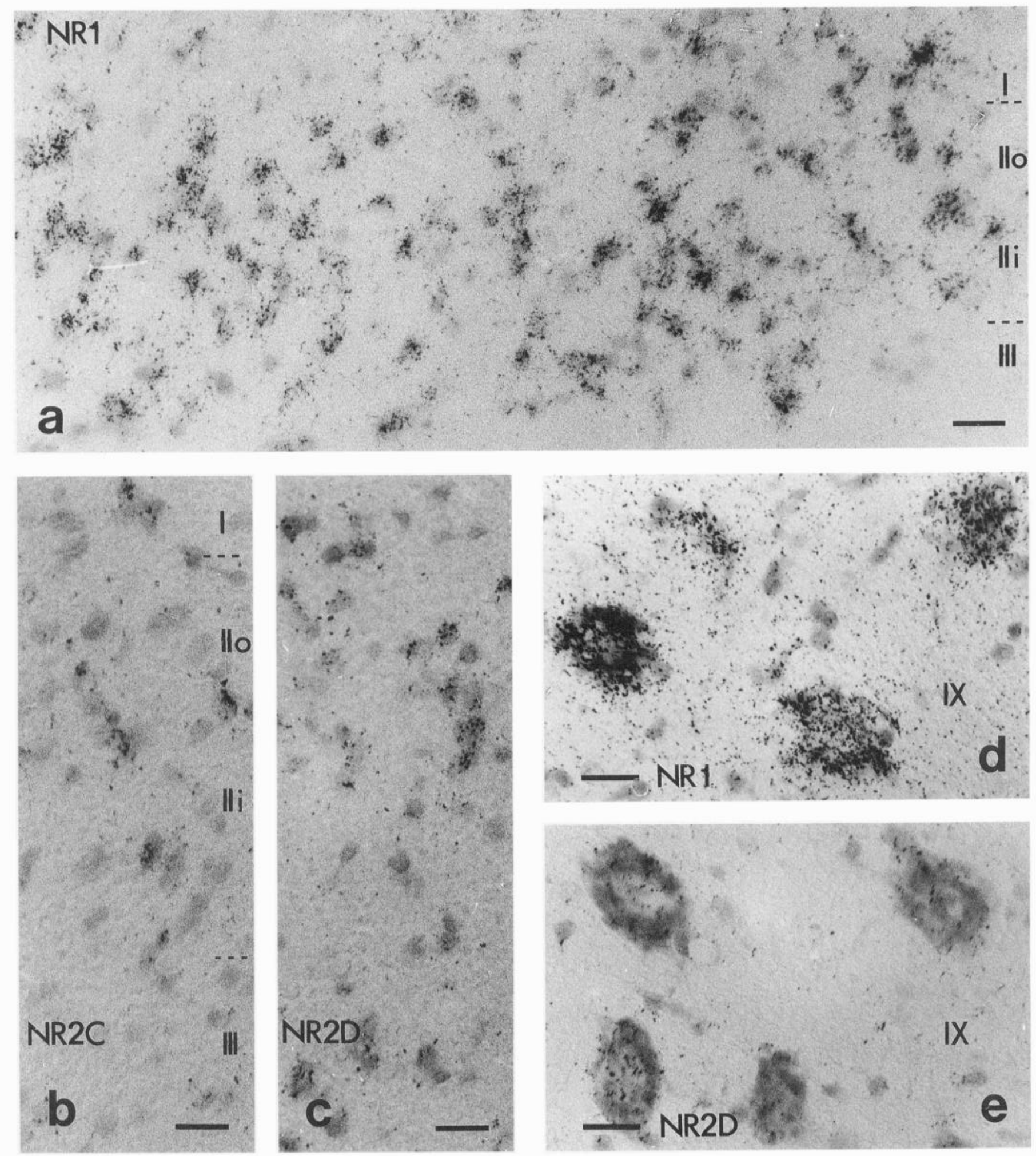

Figure 10. High-power bright-field emulsion autoradiographs illustrating expression of NMDA receptor subunit genes in the spinal cord. $a$, Many cells in the substantia gelatinosa express the NR1 subunit gene. $b$, occasional cells in the gelatinosa contain the NR2C subunit mRNA. $c$, Numerous cells in the substantia gelatinosa express the NR2D subunit gene at low levels. $d$, NR1 subunit gene expression in motor neurons. $e$, NR2D subunit gene expression in motor neurons. Roman numerals indicate Rexed laminae. Scale bars: $a, 30 \mu \mathrm{m} ; b-e, 20 \mu \mathrm{m}$.

Figure 11. Macroscopic $x$-ray images of the distribution of high-affinity AMPA receptor subunit $(a-d)$ and high-affinity kainate receptor subunit mRNAs $(e-g)$ in the PAG in serial sections from caudal (left, level of inferior colliculi) to rostral (right, level of hippocampus). $a$, GluR-A; $b$, GluRB; $c$, GluR-C; $d$, GluR-D. GluR-A and -B transcripts are most abundant with no overt differences between caudal and rostral areas of the central gray, pag. $r f$, reticular formation. $e$, GluR-7; $f$, GluR-5; $g$, GluR-6 corresponding to the upper anatomical caudal/rostral level. GluR-7 probe gives low signal in the PAG region. For anatomical orientation, see matching Nissl-counterstained slices (Fig. $13 f$ ). Scale bars, $1500 \mu \mathrm{m}$. 

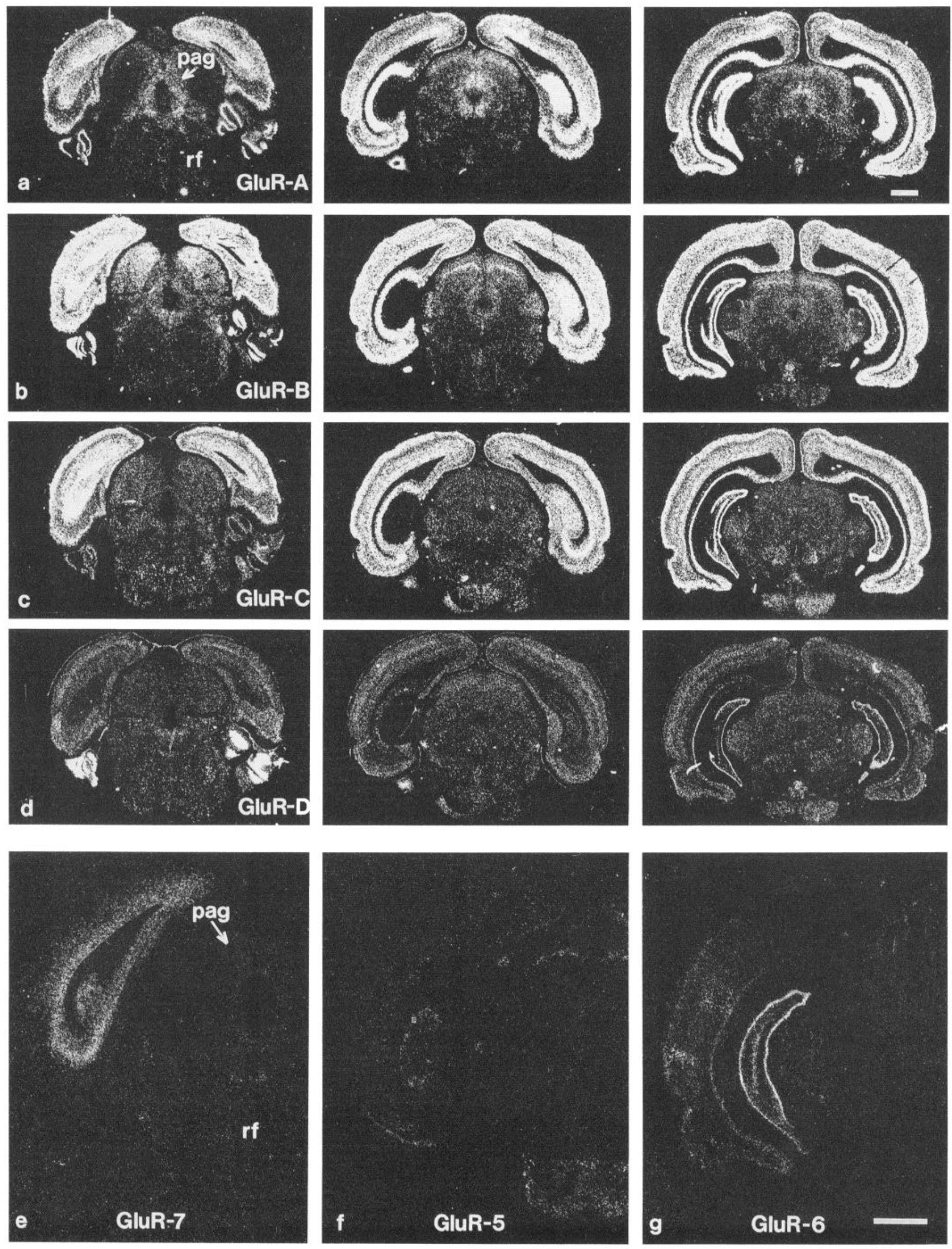

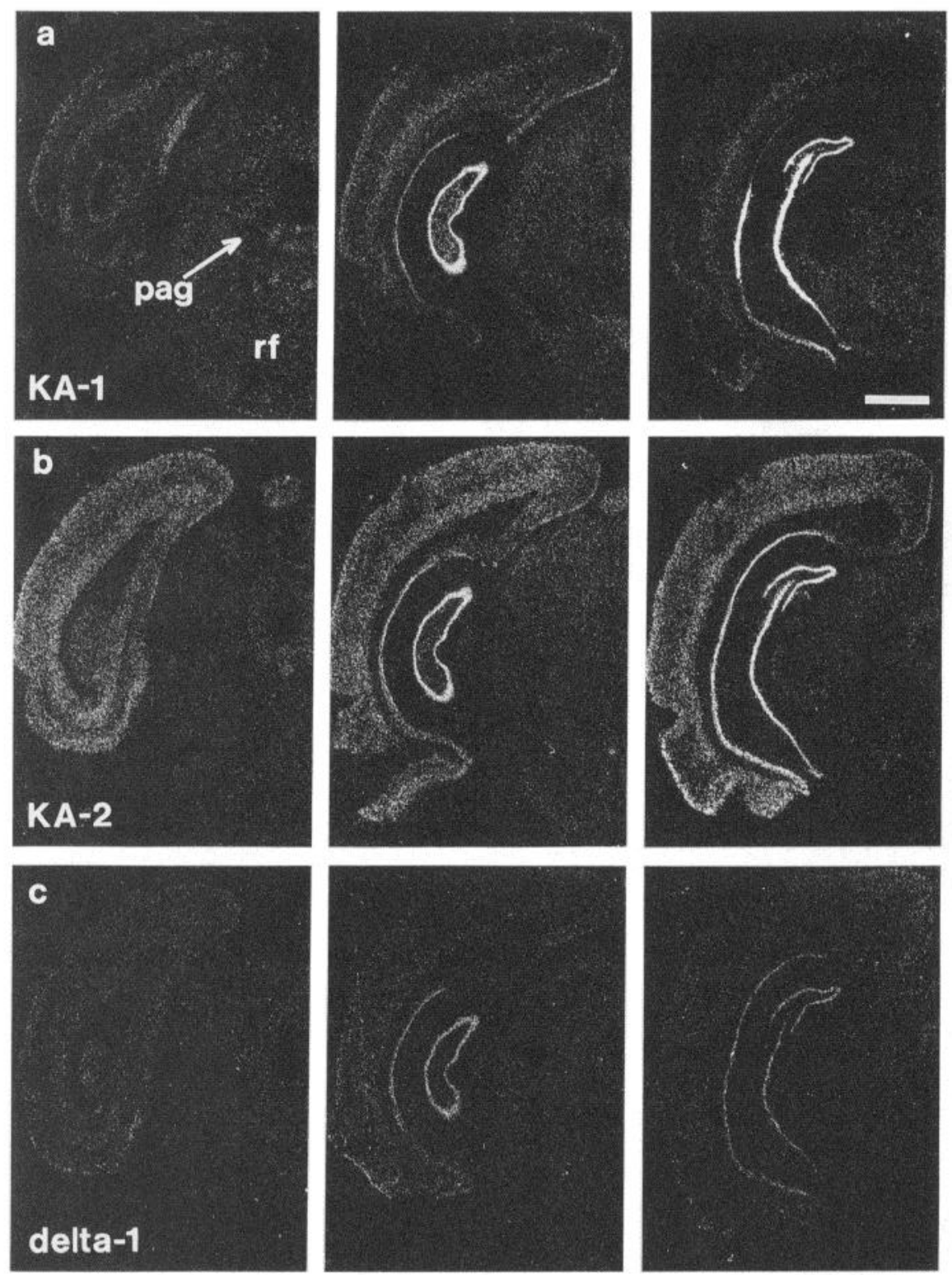

Figure 12. Macroscopic x-ray images of the distribution of high-affinity kainate receptor subunit mRNAs in the PAG in serial sections from caudal (left, level of inferior colliculi) to rostral (right, level of hippocampus). $a, \mathrm{KA}-1 ; b, \mathrm{KA}-2 ; c$ $\delta-1 ; d, \delta-2$. Note the very low signal of KA-1 and -2 in the PAG and reticular formation $(r f)$. For anatomical orientation see matching Nissl-counterstained slices (Fig. 13f ). Scale bar, 2000 $\mu \mathrm{m}$.
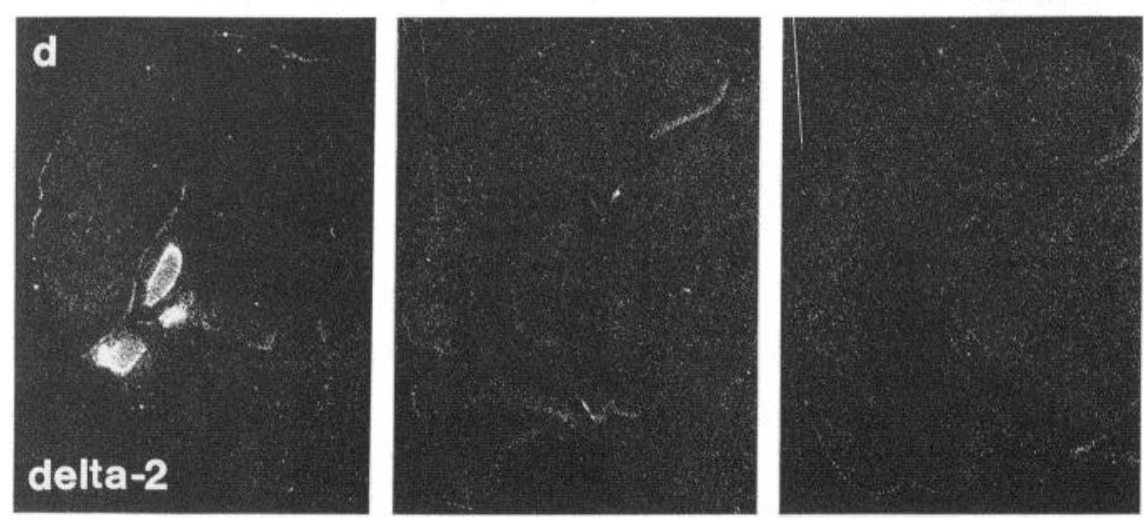

Figure 13. Macroscopic x-ray images of the distribution of NMDA receptor subunit mRNAs in the PAG in serial sections from caudal (left, level of inferior colliculi) to rostral (right, level of hippocampus), $a, \mathrm{NR} 1 ; b$, NR2A; $c$, NR2B; $d$, NR2C; $e$, NR2D; $f$ matching Nissl-counterstained slices. NR 1 mRNA is massively expressed, compared to missing signal for NR2A and NR2B and the very low signals for NR2C and NR2D. Note the detection of high levels of NR2C signal in the pineal gland. $c b$, cerebellum; $c o$, cortex; $h i$, hippocampus; $i c$, inferior colliculus; $p a g$, periaqueductal gray; $p i$, pineal gland; $p o$, pons; $s c$, superior colliculus; $r f$, reticular formation. Scale bar, $1500 \mu \mathrm{m}$. 


this remains unknown (Sommer et al., 1990; Jonas and Sakmann 1992). AMPA receptor configurations lacking the GluR-B subunit are permeable to $\mathrm{Ca}^{2+}$ as well as $\mathrm{Na}^{+}$or $\mathrm{K}^{+}$ions and show doubly rectifying current-voltage relationships (Hollmann et al., 1991; Hume et al., 1991; Burnashev et al., 1992a). Thus, since the large GluR-C-positive neurons in lamina IV/V contain very little GluR-B mRNA, they might bear $\mathrm{Ca}^{2+}$-permeable AMPA/low-affinity kainate receptors. The consequences of $\mathrm{Ca}^{2+}$ entry into the cell via non-NMDA receptors in a voltage-independent manner is not known, but the phenomenon is consistent with reports of divalent cation-permeable non-NMDA receptors from other areas of the CNS (lino et al., 1990; Pruss et al., 1991; Burnashev et al., 1992b; Müller et al., 1992). However, the majority of AMPA receptors in the spinal cord probably contain the GluR-B subunit, and thus have a very low $\mathrm{Ca}^{2+}$ permeability (Hollmann et al., 1991; Burnashev et al., 1992b). For example, in the higher midbrain centers that are related to pain, the most prominent AMPA/low-affinity kainate receptor subtype is likely to be a GluR-A/GluR-B heteromeric.

GluR-B transcripts are unique in that they undergo an editing process during which an adenosine residue is converted into guanosine (Sommer et al., 1991), generating an arginine instead of a glutamine in a predicted channel-forming region of the protein. It is this arginine residue that controls the $\mathrm{Ca}^{2+}$ permeability discussed above (Hollmann et al., 1991; Hume et al., 1991; Burnashev et al., 1992b). Possibly connected with the RNA editing mechanism is the reproducible high level of the GluR-B autoradiographic signal in the nucleus of motor neurons, with a relatively reduced signal in the cytoplasm (Fig. $5 b$ ). I'his is easy to observe in motor neurons because of the large size and clear staining of the cell components. All other subunit probes consistently detect more signal in the cytoplasm of motor neurons.

\section{High-affinity kainate receptors}

It is likely that most electrophysiological studies of "kainate" receptors in the spinal cord have concerned the AMPA/lowaffinity kainate sites, which are characterized by nondesensitizing current responses to kainate (e.g., Trussel et al., 1988; Gerber and Randic, 1989; Smith et al., 1991; Yoshimura et al., 1991). High-affinity kainate receptors whose currents exhibit rapid desensitization to kainate have not been functionally detectable in the CNS, even though their subunit mRNAs and binding sites are often abundant (Monaghan and Cotman, 1982; Bettler et al., 1990, 1992; Egebjerg et al., 1991; Werner et al., 1991; Lomeli et al., 1992; Wisden and Seeburg, 1993b). This electrophysiological "invisibility" might be explained because these receptors could be located on dendrites and thus are difficult to patch clamp (Good et al., 1992). Although electrophysiological responses to dendritically applied kainate $(100 \mu \mathrm{M})$ can be detected on acutely dissociated dorsal horn neurons, with these responses being even larger than those obtained from the cell body (Arancio et al., 1993), it is not clear which type(s) of kainate receptor is activated. However, rapidly desensitizing high-affinity kainate receptors that have properties identical to certain combinations of recombinant subunits are found on dorsal root ganglia (Bettler et al., 1990; Huettner, 1990; Sommer et al., 1992).

In contrast to the situation in some other CNS structures (e.g., Wisden and Seeburg, 1993b), high-affinity kainate receptor subunit $\mathrm{mRNAs}$ are not abundant in either the spinal cord or PAG. Indeed, the GluR-6 subunit mRNA is altogether undetectable using our in situ hybridization assay and thus probably has no role in nociception or movement control in these structures. In the PAG, high-affinity kainate receptors may consist of the KA-2 and GluR-7 subunits. In the dorsal horn, there are occasional cells expressing the GluR-5 and -7 subunit genes, and rather more cells that contain the KA-2 mRNA (Fig. 7a,b,d). Thus, the GluR-5, -7, and KA-2 mRNAs are probably found in a subset of cells expressing the AMPA/low-affinity (GluR-A, -D) subunits. The weak presence of the orphan subunit $\delta-1$ and -2 mRNAs in the spinal cord does not reveal anything about their in vivo function. Motor neurons express the KA-1 gene, the orphan subunits $\delta-1$ and -2 at low levels, and the GluR-5 gene very weakly in a small number of cells. However, a preliminary report of GluR-5 gene expression in the ventral horn of the rat (Fan et al., 1992) together with the finding of a close chromosomal vicinity of the human GluR -5 gene and of a mutant gene causing familial amyotrophic lateral sclerosis (Eubanks et al., 1993; Gregor et al., 1993; Potier et al., 1993) were taken as convergent evidence that a mutated GluR-5 gene may be responsible for the familial form of the neurodegenerative disease (Eubanks et al., 1993). In contrast, the present study in the rodent and another study in chick $\alpha$-motor neurons (Lowe et al., 1992) demonstrate only a low level of GluR-5 expression in motor neurons. Indeed, the familial form of amyotrophic lateral sclerosis has now been shown to be associated with a mutation in the radical-scavenging enzyme cytosolic superoxide dismutase (Rosen et al., 1993). Nevertheless, kainate/AMPA receptors could still be indirectly involved in the pathology of motor neuron degeneration. One hypothesis (see McNamara and Fridovich, 1993, for review) is that physiological activation of kainate/AMPA receptors on motor neurons over the course of a lifetimc, combincd with the decreascd dismutasc activity, leads to an accumulation of free radicals and to the gradual death of motor neurons. If this is true, then as part of a potential therapeutic option, it will be important to take into account the EAA receptor subunit combinations on motor neurons.

\section{NMDA receptor heterogeneity}

There is a puzzling feature of the NMDA receptor system in the spinal cord. The NR1 subunit mRNA is present in virtually every neuron at high levels, but there is a large abundance mismatch between NR 1 and the members of the NMDAR 2 family (NR2C and NR2D) found in this area of the CNS. As is the case for the GluR-6 subunit, the NR2A and NR2B subunit gene expression is not detectable using our in situ hybridization method in the gray matter of the spinal cord and in the PAG and reticular formation. The NR2C subunit $m R N A$ is present in only a very small number of cells in the substantia gelatinosa, whereas the NR2D subunit mRNA is more universally distributed, but rather weakly in comparison to NR1. An identical situation applies to the NR1/NR2D mRNA ratio noted in the PAG. Several reasons might account for the abundance discrepancy between NR1 mRNA and that of the other subunits. For example, many NMDA receptors in the cord and PAG could be homomeric assemblies of the NR1 subunit, or the high ratio of NR 1 mRNA to that of the other subunits might imply something about the stoichiometry of the subunits in the receptor complex. Studies with subunit-specific antibodies will reveal the abundance of the NR2 proteins. In the cord, the turnover of NR2 subunit mRNA might be very low. Alternatively, there could be unknown NMDA receptor subunits. The distribution of NR1 splice variants has not yet been determined, but our 
NR 1 oligonucleotide probe will hybridize to all splice variants (Sugihara et al., 1992).

\section{Spatial mismatches between $m R N A$ and binding sites}

An interesting observation is the mismatch between receptor sites identified by ligand autoradiography and the cell bodies identified by the in situ hybridization studies. All autoradiographic studies highlight the enrichment of the three ionotropic EAA receptor classes in the dorsal horn (Monaghan and Cotman, 1982, 1985; Jansen et al., 1990; Mitchell and Anderson, 1991; Shaw et al., 1991; Kalb et al., 1992), yet in situ hybridization suggests that both AMPA/low-affinity kainate and NMDA receptors will also be abundant in the ventral horn in addition to their concentration in the substantia gelatinosa. Specifically, motor neurons express the GluR-B, -C, -D (as discussed above), KA-1, NR1, and NR2D genes and more weakly those of GluR-A, $\delta-1$, and $\delta-2$. However, in the spinal cord of the cat, the density of NMDA binding sites in the dorsal horn is approximately three times that found in ventral horn, the density of AMPA sites four times higher, and that of the high-affinity kainate sites twice as high (Mitchell and Anderson, 1991), although some of the high-affinity kainate sites may reside on primary afferent terminals (Bettler et al., 1990; Huettner, 1990; Sommer et al., 1992). Similar results have been found in the rat (Monaghan and Cotman, 1982, 1985), mouse (Gonzalez et al., 1993), and human cord (Jansen et al., 1990). Alternatively, in addition to a difference in binding site densities, the observation of greater binding in the dorsal horn than the ventral could reflect either a regional difference in lipid quenching or a difference in affinities between different subtypes.

Indeed, in the neonatal rat spinal cord, two distinct populations of NMDA receptors can be identified: one population labeled with ${ }^{3} \mathrm{H}$-glutamate and the noncompetitive channel blocking agent ${ }^{3} \mathrm{H}-\mathrm{MK}-801$ is present throughout the spinal gray matter, whereas the NMDA receptor antagonist ${ }^{3} \mathrm{H}-\mathrm{CGP}\left({ }^{3} \mathrm{H}\right.$ labeled chorionic growth hormone prolactin 39653) labels only the dorsal horn (Kalb et al., 1992). NMDA-sensitive ${ }^{3} \mathrm{H}$-glutamate binding also decreases in the mouse ventral horn during postnatal development (Gonzalez et al., 1993). Thus, these authors indicate that motor neurons express NMDA receptors, but only in the neonate (Kalb et al., 1992).

Nevertheless, a study using adult human cord has reported focal areas of high ${ }^{3} \mathrm{H}-\mathrm{MK}-801$ binding corresponding to lower motor neurons in the ventral horn (Shaw et al., 1991). Further, NMDA receptor activation of adult motor neurons contributes to background activity and the formation of long-latency EPSPs in these cells (Polc, 1985, 1987; Jiang et al., 1991). In conclusion, NMDA receptors are likely to be important in motor as well as sensory spinal synaptic transmission. A candidate motor neuron NMDA receptor would be an NR1/NR2D configuration. Similarly, there is ample electrophysiological evidence for AMPAlow-affinity kainate receptors on motor neurons (see introductory remarks for references), in agreement with the in situ hybridization data suggesting a GluR-A/-B/-C subtype, even though there is very little ${ }^{3} \mathrm{H}$-AMPA binding over the ventral horn.

Another example of a spatial mismatch between mRNA and binding sites is that of the $\mathrm{G} \triangle \mathrm{BA} \mathrm{A}_{\mathrm{A}}$ receptor. In situ hybridization analysis predicts the abundant presence of an $\alpha 2 \beta 3 \gamma 2$ subtype of $\mathrm{GABA}_{\mathrm{A}}$ receptors on motor neurons (Persohn et al., 1991; Wisden et al., 1991a). Consistent with this, motor neurons receive GABAergic inhibition from Renshaw cells and have GA$\mathrm{BA}_{\mathrm{A}}$ activatable chloride channels (Haefely and Polc, 1986). Yet,
$\mathrm{GABA}_{\mathrm{A}}$ receptor ligands preferentially bind to sites in the dorsal horn (Persohn et al., 1991, and references therein). One possible solution to this problem for both GABA and glutamate receptors is that dendrites of motor neurons extend far from the cell soma into more dorsal regions, and hence the receptors may reside on the dendrites.

\section{Rationale for receptor subtypes}

Why should different cell types in the spinal cord contain different proportions of receptor subunit mRNAs? For all classes of EAA ionotropic receptors, different combinations of subunits show differing channel kinetics, dose-response characteristics, or voltage dependence and ion selectivities (Boulter et al., 1990; Nakanishi et al., 1990; Sommer et al., 1990; Hollmann et al., 1991; Verdoorn et al., 1991; Burnashev et al., 1992a,b; Herb et al., 1992; Köhler et al., 1993). The functional differences between these receptor subtypes may be tailored to fit the requirements of the particular neuronal circuit in which they are activated. For example, AMPA/low-affinity kainate receptor channels in the cochlea nucleus of the chicken have unusually rapid onset and termination of their currents. These channel properties are uniquely suited to the transmission of timing information and allows phase locking of synaptic signals to auditory stimuli (Raman and Trussell, 1992). Similar considerations probably apply to different neuronal types in the spinal cord. Ionotropic EAA receptors involved in pattern-generating circuits on motor neurons may need to respond quicker and produce larger currents to transmitter activation than receptors involved in long-term adaptational responses to sensory stimuli (e.g., Haley et al., 1990).

\section{References}

Agrawal SG, Evans RH (1986) The primary afferent depolarizing action of kainate in the rat. Br J Pharmacol 87:345-355.

Andrezik JA, Beitz AJ (1985) Reticular formation, central grey and related tegmental nuclei. In: The rat nervous system, Vol 2, Hindbrain and spinal cord (Paxinos G, ed), pp 1-28. Sydney: Academic.

Arancio O, Yoshimura M, Murase K, MacDermott AB (1993) The distribution of excitatory amino acid receptors on acutely dissociated dorsal horn neurons from postnatal rats. Neuroscience 52:159-167.

Basbaum AI, Fields HL (1984) Endogenous pain control systems: brainstem, spinal pathways and endorphin circuitry. Annu Rev Neurosci 7:309-338.

Beitz AJ (1982) The organization of afferent projections to the midbrain periaqueductal gray of the rat. Neuroscience 8:133-159.

Bekkers JM, Stevens CF (1989) NMDA and non-NMDA receptors are colocalized at individual excitatory synapses in cultured rat hippocampus. Nature 341:233.

Bekkers JM, Stevens CF (1990) Computational implications of NMDA receptor channels. Cold Spring Harbor Symp Quant Biol 55:131-135.

Bettler B, Boulter J, Hermans-Borgmeyer I, O'Shea-Greenfield A, Deneris ES, Moll C, Borgmeyer U, Hollmann M, Heinemann S (1990) Cloning of a novel glutamate receptor subunit, GluR-5: expression in the nervous system during development. Neuron 5:583-595.

Bettler B, Egebjerg J, Sharma G, Pecht G, Hermans-Borgmeyer I, Moll $C$, Stevens CF, Heinemann S (1992) Cloning of a putative glutamate receptor: a low affinity kainate-binding subunit. Neuron 8:257-265.

Boulter J, Hollmann M, O'Shea-Greenfield A, Hartley M, Deneris ES, Maron C, Heinemann S (1990) Molecular cloning and functional expression of glutamate receptor subunit genes. Science 249:10331037.

Brichta AM, Grant G (1985) Cytoarchitectural organization of the spinal cord. In: The rat nervous system, Vol 2, Hindbrain and spinal cord (Paxinos G, ed), pp 293-301. Sydney: Academic.

Burke RE (1990) Spinal cord: ventral horn. In: The synaptic organization of the brain, 3d ed (Shepherd GM, ed), pp 88-132. New York: Oxford UP. 
Burnashev N, Monyer H, Seeburg PH, Sakmann B (1992a) Divalent ion permeability of AMPA receptor channels is dominated by the edited form of a single subunit. Neuron 8:189-198.

Burnashev N, Khodorova A, Jonas P, Helm PJ, Wisden W, Monyer H, Seeburg PH, Sakmann B (1992b) Calcium-permeable AMPA kainate receptors in fusiform cerebellar glial cells. Science 256:15661570 .

Cazalets JR, Sqalli-Houssaini Y, Clarac F (1992) Activation of the central pattern generators for locomotion by serotonin and excitatory amino acids in neonatal rat. $J$ Physiol (Lond) 455:187-204.

Chaouch A, Menetrey D, Binder D, Besson JM (1983) Neurons at the origin of the medial component of the bulbopontine spinoreticular tract in the rat: an anatomical study using horseradish peroxidase retrograde transport. J Comp Neurol 214:309-320.

Chen L, Huang LYM (1991) Sustained potentiation of NMDA receptor-mediated glutamate responses through activation of protein kinase $C$ by a $\mu$ opioid. Neuron 7:319-326.

Curtis DR, Phillis JW, Watkins JC (1959) Chemical excitation of spinal neurones. Nature 183:611-612.

Davies SN, Lodge D (1987) Evidence for involvement of $N$-methylD-aspartate receptors in "wind-up" of class 2 neurons in the dorsal horn of the rat. Brain Res 424:402-406.

Di-Prisco GV, Wallen P, Grillner S (1990) Synaptic effects of intraspinal stretch receptor neurons mediating movement-related feedback during locomotion. Brain Res 530:161-166.

Dougherty PM, Palecek J, Paleckova V, Sorkin LS, Willis WD (1992) The role of NMDA and non-NMDA amino acid receptors in the excitation of primate spinothalamic tract neurons by mechanical, chemical, thermal and electrical stimuli. J Neurosci 12:3025-3041.

Egebjerg J, Bettler B, Hermans-Borgmeyer I, Heinemann S (1991) Cloning of a cDNA for a glutamate receptor subunit activated by kainate but not by AMPA. Nature 351:745-748.

Euhanks JH, Puranam RS, Kleckner NW, Bettler B, Heinemann SF, McNamara JO (1993) The gene encoding the glutamate receptor subunit GluR5 is located on human chromosome 21q21.1-22.1 in the vicinity of the gene for familial amyotrophic lateral sclerosis. Proc Natl Acad Sci USA 90:178-182.

Fan SG, Zukin RS, Pellegrini-Giampietro D, Ault B (1992) Glutamate receptor gene expression in spinal cord of arthritic rats. Soc Neurosci Abstr 18:89.

Fields HL, Basbaum AI (1978) Brainstem control of spinal paintransmission neurons. Annu Rev Physiol 40:217-248.

Gasic GP, Hollmann M (1992) Molecular neurobiology of glutamate receptors. Annu Rev Physiol 54:507-536.

Gerber G, Randic M (1989) Excitatory amino acid-mediated components of synaptically evoked input from dorsal roots to deep dorsal horn neurons in the rat spinal cord slice. Neurosci I ett 106:211-219.

Giesler GJ, Menetrey D, Basbaum AI (1979) Differential origins of spinothalamic tract projections to medial and lateral thalamus in the rat. J Comp Neurol 184:107-126.

Gonzalez DL, Fuchs JL, Droge MH (1993) Distribution of NMDA receptor binding in developing mouse spinal cord. Neurosci Lett 151: 134-137.

Good PF, Moran T, Rogers SW, Heinemann S, Morrison JH (1992) Distribution of the kainate class glutamate receptor subunits (GluR5GluR7) in the temporal cortex of the macaque: localization to identified projection neurons of the entorhinal cortex. Soc Neurosci Abstr 18:1466.

Gregor P, Reeves RH, Jabs EW, Yang X, Dackowski W, Rochelle JM, Brown RH, Haines JL, O'Hara BF, Uhl GR, Seldin MF (1993) Chromosomal localization of glutamate receptor genes: relationship to familial amyotrophic lateral sclerosis and other neurological disorders of mice and humans. Proc Natl Acad Sci USA 90:3053-3057.

Grillner S, Matsushima T (1991) The neural network underlying locomotion in lamprey-synaptic and cellular mechanisms. Neuron $7: 1-15$.

Haefely W, Polc P (1986) Physiology of GABA enhancement by benzodiazepines and barbiturates. In: Benzodiazepine/GABA receptors and chloride channels (Olsen R, Venter JC, eds), pp 97-133. New York: Liss.

Haley JE, Sullivan AF, Dickenson AH (1990) Evidence for spinal $N$-methyl-D-aspartate receptor involvement in prolonged chemical nociception in the rat. Brain Res 518:218-226.

Headley PM, Grillner S (1990) Excitatory amino acids and synaptic transmission: the evidence for a physiological function. Trends Pharmacol Sci 11:205-211.

Herb A, Burnashev N, Werner P, Sakmann B, Wisden W, Seeburg PH (1992) The KA-2 subunit of excitatory amino acid receptors shows widespread expression in brain and forms ion channels with distantly related subunits. Neuron 8:775-785.

Hollmann M, O'Shea-Greenfield A, Rogers SW, Heinemann S (1989) Cloning by functional expression of a member of the glutamate receptor family. Nature 342:643-648.

Hollmann M, Hartley M, Heinemann S (1991) Calcium permeability of KA-AMPA-gated glutamate receptor channels: dependence on subunit composition. Science 252:851-853.

Huettner JE (1990) Glutamate receptor channels in rat DRG neurons: activation by kainate and quisqualate and blockade of desensitization by Con A. Neuron 5:255-266.

Hume RI, Dingledine R, Heinemann S (1991) Identification of a site in glutamate receptor subunits that controls calcium permeability. Science 253:1028-1031.

Iino M, Ozawa S, Tsuzuki K (1990) Permeation of calcium through excitatory amino acid receptor channels in cultured rat hippocampal neurones. J Physiol (Lond) 424:151-165.

Ikeda K, Nagasawa M, Mori H, Araki K, Sakimura K, Watanabe M, Inoue Y, Mishina M (1992) Cloning and expression of the $\epsilon 4$ subunit of the NMDA receptor channel. FEBS Lett 313:34-38.

Jansen KLR, Faull RLM, Dragunow M, Waldrogel H (1990) Autoradiographic localization of NMDA, quisqualate and kainic acid receptors in human spinal cord. Neurosci Lett 108:53-57.

Jensen TS, Yaksh TL (1992) Brainstem excitatory amino acid receptors in nociception: microinjection mapping and pharmacological characterization of glutamate-sensitive sites in the brainstem associated with algogenic behavior. Neuroscience 46:533-547.

Jessel TM, Yoshioka K, Jahr CE (1986) Amino acid receptor-mediated transmission at primary afferent synapses in rat spinal cord. J Exp Biol 124:239-258.

Jiang ZG, Shen E, Wang MY, Dun NJ (1991) Excitatory postsynaptic potentials evoked by ventral root stimulation in neonate rat motorneurons in vitro. J Neurophysiol 65:57-66.

Jonas P, Sakmann B (1992) Glutamate receptor channels in isolated patches from $C A 1$ and $C A 3$ pyramidal cells of rat hippocampal slices. J Physiol (Lond) 455:143-171.

Jones KA, Baughman RW (1991) Both NMDA and non-NMDA subtypes of glutamate receptors are concentrated at synapses on cerebral cortical neurons in culture. Neuron 7:593-603.

Jordan LM, Brownstone RM, Noga BR (1992) Control of functional systems in the brainstem and spinal cord. Curr Opin Neurobiol 2:794801.

Kalb RG, Lidow MS, Halsted MJ, Hockfield S (1992) $N$-methyl-Daspartate receptors are transiently expressed in the developing spinal cord ventral horn. Proc Natl Acad Sci USA 89:8502-8506.

Keinänen K, Wisden W, Sommer B, Werner P, Herb A, Verdoorn TA, Sakmann B, Seeburg PH (1990) A family of AMPA-selective glutamate receptors. Science 249:556-560.

Köhler M, Burnashev N, Sakmann B, Seeburg PH (1993) Determinants of $\mathrm{Ca}^{2+}$ permeability in both TM1 and TM2 of high-affinity kainate receptor channels: diversity by RNA editing. Neuron 10:491500.

Kutsuwada T, Kashiwabuchi N, Mori H, Sakimura K, Kushiya E, Araki K, Meguro H, Masaki H, Kumanishi T, Arakawa M, Mishina M (1992) Molecular diversity of the NMDA receptor channel. Nature $358: 36-41$.

Lai YY, Siegel JM (1991) Pontomedullary glutamate receptors mediating locomotion and muscle tone suppression. J Neurosci 11:29312937.

Lomeli H, Wisden W, Köhler M, Keinänen K, Sommer B, Seeburg PH (1992) High-affinity kainate and domoate receptors in rat brain. FEBS Lett 307:139-143.

Lomeli H, Sprengel R, Laurie DJ, Köhr G, Herb A, Seeburg PH, Wisden W (1993) The rat delta-1 and delta-2 subunits extend the excitatory amino acid receptor family. FEBS Lett 315:318-322.

Long SK, Smith DA, Siarey RJ, Evans RH (1990) Effect of 6-cyano2,3-dihydroxy-7-nitro-quinoxaline (CNQX) on dorsal root-, NMDA-, kainate- and quisqualate-mediated depolarization of rat motor neurones in vitro. $\mathrm{Br} \mathrm{J}$ Pharmacol 100:850-854.

Lowe D, Leach P, Temkin R, Smith DO (1992) Expression of glu- 
tamate receptor subunits in chick alpha-motoneurons. Soc Neurosci Abstr 18:89.

Mantyh PW, Peschanski M (1982) Spinal projections from the periaqueductal grey and dorsal raphe in the rat, cat and monkey. Neuroscience 7:2769-2776.

Martin LJ, Blackstone CD, Levey AI, Huganir RL, Price DL (1993) AMPA glutamate receptor subunits are differentially distributed in rat brain. Neuroscience 53:327-358.

McCrimmon DR, Smith JC, Feldman JL (1989) Involvement of excitatory amino acids in neurotransmission of inspiratory drive to spinal respiratory motorneurons. J Neurosci 9:1910-1921.

McNamara JO, Fridovich I (1993) Did radicals strike Lou Gehrig? Nature 362:20-21

Meguro H, Mori H, Araki K, Kushiya E, Kutsuwada T, Yamazaki M, Kumanishi T, Arakawa M, Sakimura K, Mishina M (1992) Functional characterization of a heteromeric NMDA receptor channel expressed form cloned cDNAs. Nature 357:70-74.

Mitchell JJ, Anderson KJ (1991) Quantitative autoradiographic analysis of excitatory amino acid receptors in the cat spinal cord. Neurosci Lett 124:269-272.

Monaghan DT, Anderson KJ (1991) Heterogeneity and organization of excitatory amino acid receptors and transporters. In: Excitatory amino acids and synaptic function (Wheal $H$, Thomson $A$, eds), pp 33-54. Sydney: Academic.

Monaghan DT, Cotman CW (1982) The distribution of $\left[{ }^{3} \mathrm{H}\right]$ kainic acid binding sites in rat CNS as determined by autoradiography. Brain Res 252:91-100.

Monaghan DT, Cotman CW (1985) Distribution of NMDA-sensitive $\mathbf{L}-\left[{ }^{3} \mathrm{H}\right]$ glutamate binding sites in rat brain as determined by quantitative autoradiography. J Neurosci 5:2909-2919.

Monyer H, Sprengel R, Schoepfer R, Herb A, Higuchi M, Lomeli H, Burnashev N, Sakmann B, Seeburg PH (1992) Heteromeric NMDA receptors: molecular and functional distinction of subtypes. Science 256:1217-1221.

Moriyoshi K, Masu M, Ishii T, Shigemoto R, Mizuno N, Nakanishi S (1991) Molecular cloning and characterization of the rat NMDA receptor. Nature 354:31-37

Morris R (1989) Responses of spinal dorsal horn neurones evoked by myelinated primary afferent stimulation are blocked by excitatory amino acid antagonists acting at kainate/quisqualate receptors. Neurosci Lett 105:79-85.

Müller T, Möller T, Berger T, Schnitzer J, Kettenmann H (1992) Calcium entry through kainate receptors and resulting potassium-channel blockade in Bergmann glial cells. Science 256:1563-1566.

Nakanishi N, Shneider NA, Axel R (1990) A family of glutamate receptor genes: evidence for the formation of heteromultimeric receptors with distinct channel properties. Neuron 5:569-581.

Nakanishi S (1992) Molecular diversity of glutamate receptors and implications for brain function. Science 258:597-603.

Nelson SB, Sur M (1992) NMDA receptors in sensory information processing. Curr Opin Neurobiol 2:484-488.

Persohn E, Malherbe P, Richards JG (1991) In situ hybridization histochemistry reveals a diversity of $\mathrm{GABA}_{\mathrm{A}}$ receptor subunit mRNAs in neurons of the rat spinal cord and dorsal root ganglia. Neuroscience $42: 497-507$

Polc P (1985) 2-Amino-7-phosphonoheptanoic acid depresses motorneurons and polysynaptic reflexes in the cat spinal cord. Eur J Pharmacol 117:387-389.

Polc $P$ (1987) NMDA receptors mediate background and excessive activity of motorneurons in the spinal cord. Eur J Pharmacol 144: $113-115$.

Potier MC, Dutriaux A, Lambrolez B, Bochet P, Rossier J (1993) Assignment of the human glutamate receptor gene GLUR5 to $21 \mathrm{q} 22$ by screening a chromosomal 21 YAC library. Genomics 15 :in press.

Pruss RM, Akeson RL, Racke MM, Wilburn JL (1991) Agonist-activated cobalt uptake identifies divalent cation-permeable kainate receptors on neurons and glial cells. Neuron 7:509-518.

Raman IA, Trussell LO (1992) The kinetics of the response to glutamate and kainate in neurons of the avian cochlear nucleus. Neuron 9:173-186.

Ren K, Hylden JLK, Williams GM, Ruda MA, Dubner R (1992) The effects of a non-competitive NMDA receptor antagonist, MK-801, on behavioural hyperalgesia and dorsal horn neuronal activity in rats with unilateral inflammation. Pain 50:331-344.
Rosen DR, Siddique T, Patterson D, Figlewicz DA, Sapp P, Hentati A, Donaldson D, Gotot J, O'Regan JP, Deng H-X, Rahmani Z, Krizus A, McKenna-Yasek D, Cayabyab A, Gaston SM, Berger R, Tanzi RE, Halperin JJ, Herzfeldt B, Van den Bergh R, Hung W-Y, Bird T, Deng G, Mulder DW, Smyth C, Laing NG, Soriano E, Pericak-Vance MA, Haines J, Rouleau GA, Gusella JS, Horvitz HR, Brown RH (1993) Mutations in $\mathrm{Cu} / \mathrm{Zn}$ superoxide dismutase gene are associated with familial amyotrophic lateral sclerosis. Nature 362:59-62.

Sakimura K, Morita T, Kushiya E, Mishina M (1992) Primary structure and expression of the $\gamma 2$ subunit of the glutamate receptor channel selective for kainate. Neuron $8: 267-274$.

Schouenberg J, Dickenson A (1988) Long-lasting neuronal activity in rat dorsal horn evoked by impulses in cutaneous fibres during noxious mechanical stimulation. Brain Res 439:56-63.

Shaw PJ, Ince PG, Johnson M, Perry EK, Candy J (1991) The quantitative autoradiographic distribution of $\left[{ }^{3} \mathrm{H}\right] \mathrm{MK}-801$ binding sites in the norman human spinal cord. Brain Res 539:164-168.

Sillar KT, Roberts A (1988) Unmyelinated cutaneous afferent neurons activate two types of excitatory amino acid receptor in the spinal cord of Xenopus laevis embryos. J Neurosci 8:1350-1360.

Simone DA (1992) Neural mechanisms of hyperalgesia. Curr Opin Neurobiol 2:479-483.

Smith DO, Franke C, Rosenheimer JL, Zufall F, Hatt H (1991) Glutamate-activated channels in adult rat ventral spinal cord cells. $J$ Neurophysiol 66:369-378.

Sommer B, Seeburg PH (1992) Glutamate receptor channels: novel properties and new clones. Trends Pharmacol Sci 13:291-296.

Sommer B, Keinänen K, Verdoorn TA, Wisden W, Burnashev N, Herb A, Köhler M, Takagi T, Sakmann B, Seeburg PH (1990) Flip and Flop: a cell-specific functional switch in glutamate-operated channels of the CNS. Science 249:1580-1585.

Sommer B, Köhler M, Sprengel R, Seeburg PH (1991) RNA editing in brain controls a determinant of ion flow in glutamate-gated channels. Cell 67:11-19.

Sommer B, Burnashev N, Verdoorn TA, Keinänen K, Sakmann B, Seeburg PH (1992) A glutamate receptor channel with high affinity for domoate and kainate. EMBO J 11:1651-1656.

Stevens CF (1992) No pain, no gain. Curr Biol 2:497-499.

Sugihara H, Moriyoshi K, Ishii T, Masu M, Nakanishi S (1992) Structures and properties of seven isoforms of the NMDA receptor generated by alternative splicing. Biochem Biophys Res Commun 185: 826-832.

Tölle TR, Castro-Lopes JM, Zieglgänsberger W (1989) Transient increase in excitability ("wind-up") of somatosensory neurons migh be linked to NMDA receptor-mediated processes. In: Dynamics and plasticity in neuronal systems (Elsner N, Singer W, eds), p 249. Stuttgart: Thieme.

Trussell LO, Thio LL, Zorumski CF, Fischbach GD (1988) Rapid desensitization of glutamate receptors in vertebrate central neurons. Proc Natl Acad Sci USA 85:4562-4566.

Verdoorn TA, Burnashev N, Monyer H, Seeburg PH, Sakmann B (1991) Structural determinants of ion flow through recombinant glutamate receptor channels. Science 252:1715-1718.

Werner P, Voigt M, Keinänen K, Wisden W, Seeburg PH (1991) Cloning of a putative high-affinity kainate receptor expressed predominantly in hippocampal CA3 cells. Nature 351:742-744.

Willis WD (1988) Anatomy and physiology of descending control of nociceptive responses of dorsal horn neurons: a comprehensive review. In: Progress in brain research (Fields HL, Besson JM, eds), pp 1-29. Amsterdam: Elsevier.

Willis WD, Coggeshall RE (1991) Sensory mechanisms of the spinal cord, 2d ed. New York: Plenum.

Willis WD, Trevino DL, Coulter JD, Maunz RA (1974) Responses of primate spinothalamic tract neurons to natural stimulation of hindlimb. J Neurophysiol 37:358-372.

Wisden W, Seeburg PH (1993a) Mammalian ionotropic glutamate receptors. Curr Opin Neurobiol 3:291-298.

Wisden W, Seeburg PH (1993b) A complex mosaic of high-affinity kainate receptors in rat brain. J Neurosci 13:3582-3598.

Wisden W, Gundlach AG, Barnard EA, Seeburg PH, Hunt SP (1991a) Distribution of $\mathrm{GABA}_{A}$ receptor subunit mRNAs in rat lumbar spinal cord. Mol Brain Res 10:179-183.

Wisden W, Morris BJ, Hunt SP (1991b) In situ hybridization with synthetic DNA probes. In: Molecular neurobiology - a practical ap- 
proach (Chad J, Wheal H, eds), pp 205-225. New York: Oxford UP/ IRL

Woolf CJ, Thompson SWN (1991) The induction and maintenance of central sensitization is dependent on $N$-methyl-D-aspartic acid receptor activation: implications for the treatment of post-injury pain hypersensitivity states. Pain 44:293-299.

Yamazaki M, Araki K, Shibata A, Mishina M (1992) Molecular cloning of a cDNA encoding a novel member of the mouse glutamate receptor channel family. Biochem Biophys Res Commun 183:886892.

Yoshimura M, Murase K, Arancio O, MacDermott AB (1991) Glu- tamate receptor agonist-induced inward currents in spinal dorsal horn neurons dissociated from adult rats. Neurosci Res 12:528-535.

Young AB, Fagg GE (1990) Excitatory amino acid receptors in the brain: membrane binding and receptor autoradiographic approaches. Trends Pharmacol Sci 11:126-133.

Zieglgänsberger W (1986) Central control of nociception. In: Handbook of physiology - the nervous system IV (Mountcastle VB, Bloom FE, Geiger SR, eds), pp 581-656. Baltimore: Williams \& Wilkins.

Zieglgänsberger W, Puil EA (1973) Actions of glutamatic acid on spinal neurons. Exp Brain Res 17:35-49. 